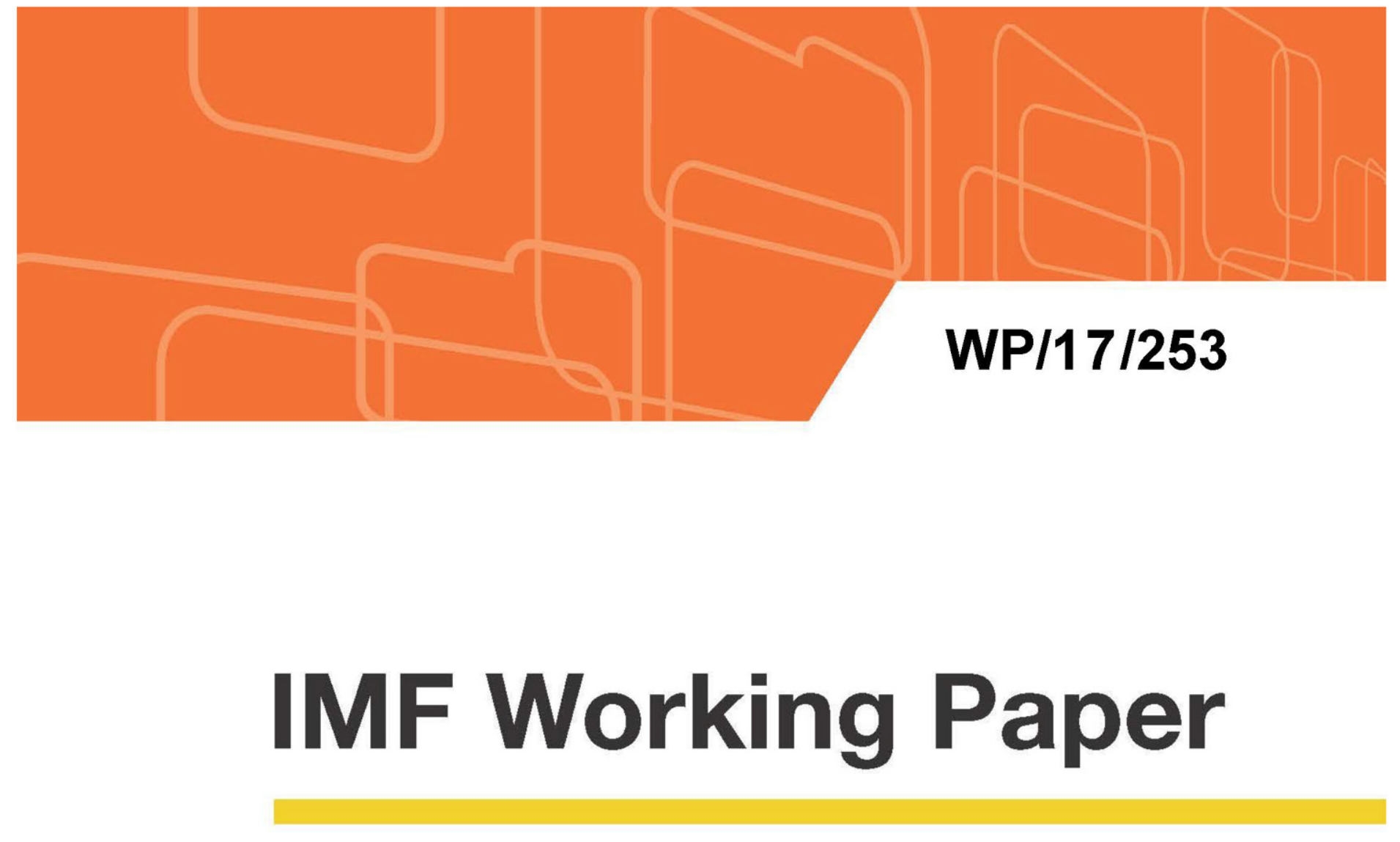

\title{
Does Import Competition Induce R\&D Reallocation? \\ Evidence from the U.S.
}

by Rui Xu and Kaiji Gong

IMF Working Papers describe research in progress by the author(s) and are published to elicit comments and to encourage debate. The views expressed in IMF Working Papers are those of the author(s) and do not necessarily represent the views of the IMF, its

Executive Board, or IMF management.

$$
\text { I N TER N A T I O N A L M O N E T A R Y F U N D }
$$




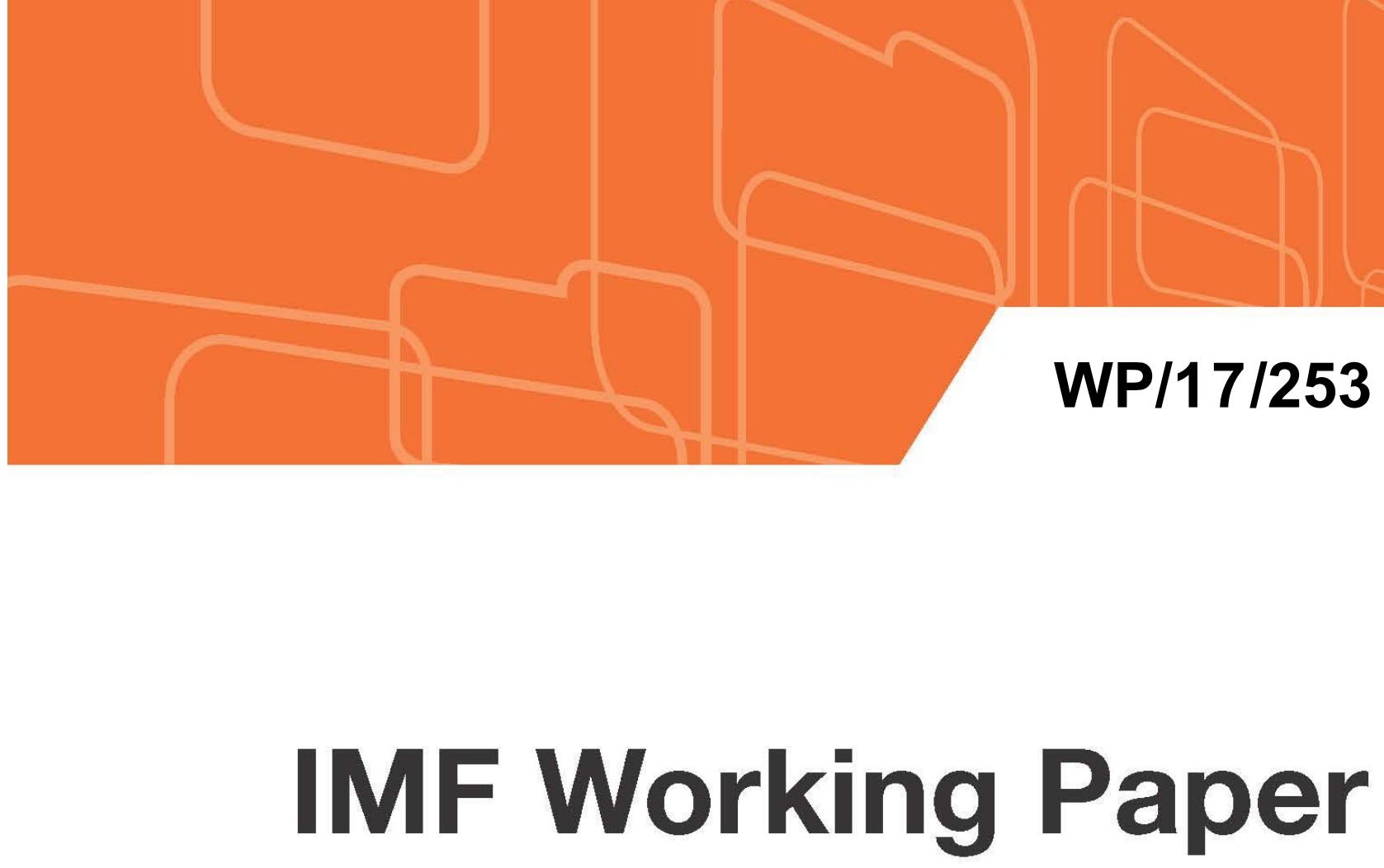

\section{Does Import Competition Induce R\&D Reallocation? \\ Evidence from the U.S.}

by Rui Xu and Kaiji Gong

IMF Working Papers describe research in progress by the author(s) and are published to elicit comments and to encourage debate. The views expressed in IMF Working Papers are those of the author(s) and do not necessarily represent the views of the IMF, its Executive Board, or IMF management.

$$
\text { I N T E R N A T I O N A L M O N E T A R Y F U N D }
$$




\title{
IMF Working Paper
}

\author{
Institute for Capacity Development
}

\section{Does Import Competition Induce R\&D Reallocation?}

Evidence from the U.S. ${ }^{1}$

Authorized for distribution by Valerie Cerra

November 2017

\section{IMF Working Papers describe research in progress by the author(s) and are} published to elicit comments and to encourage debate. The views expressed in IMF Working Papers are those of the author(s) and do not necessarily represent the views of the IMF, its Executive Board, or IMF management.

\begin{abstract}
We analyze the impact of rising import competition from China on U.S. innovative activities. Using Compustat data, we find that import competition induces $R \& D$ expenditures to be reallocated towards more productive and more profitable firms within each industry. Such reallocation effect has the potential to offset the average drop in firm-level R\&D identified in the previous literature. Indeed, our quantitative analysis shows no adverse impact of import competition on aggregate R\&D expenditures. Taking the analysis beyond manufacturing, we find that import competition has led to reallocation of researchers towards booming service industries, including business and repairs, personal services, and financial services.
\end{abstract}

JEL Classification Numbers: F14, F16, O32

Keywords: Chinese Import Competition, R\&D Expenditures, Reallocation

\footnotetext{
${ }^{1}$ Kaiji Gong is affiliated with Stanford University. Rui Xu is an economist at the IMF Institute for Capacity Development. Correspondent email: rxu@imf.org. The paper has benefited from the advice and comments from Nicholas Bloom, Pete Klenow, Chris Tonetti, seminar participants at Stanford, the ICD departmental seminars at the IMF, and the Joint Vienna Macroeconomic seminar. The opinions expressed herein are solely the responsibility of the authors and should not be interpreted as reflecting those of the IMF, its Executive Board, or IMF management.
} 


\section{Contents}

I. INTRODUCTION $\quad \underline{4}$

II. Empirical Strategy $\quad \underline{7}$

A. Measuring import competition ................ . . $\underline{7}$

B. Estimating average effect .................. $\underline{8}$

C. Within-industry reallocation ................. $\underline{9}$

III. Data And Measurement $\quad \underline{10}$

IV. Firm-LeVel Results $\quad \underline{12}$

A. Average effects . . . . . . . . . . . . . . . . . 12

B. Induced reallocation within industry ................ 14

C. Aggregating average and reallocation effects ............ 17

V. INDUSTRY-LeVEL Results $\quad \underline{18}$

A. Effect of import competition on industry-level R\&D . . . . . . . . . $\underline{19}$

B. Reallocation of researchers towards service industries . . . . . . . . . 21

VI. Discussion $\quad \underline{23}$

VII.CONCLUSIONS $\quad \underline{25}$

$\begin{array}{ll}\text { REFERENCES } & \underline{27}\end{array}$

$\begin{array}{lr}\text { APPENDICES } & 30\end{array}$

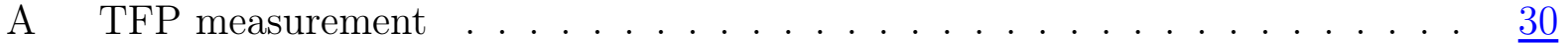

B $\quad$ KZ index and Lerner Index . . . . . . . . . . . . . . . . $\underline{32}$

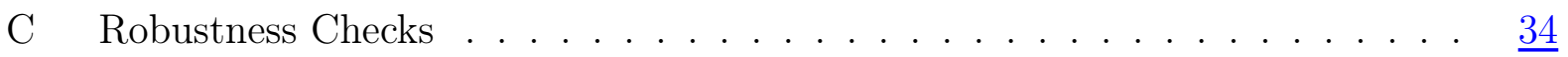

C.1 Alternative measures of import competition . . . . . . . . $\underline{34}$

C.2 Non-overlapping differences ................ . . $\underline{37}$ 
C.3 Other controls . . . . . . . . . . . . . . . . . . . $\underline{39}$

C.4 Six-year differences .................. . . $\underline{40}$

D Aggregating Firm-level Effects: Derivation . . . . . . . . . . . $\underline{42}$ 


\section{INTRODUCTION}

China's emergence as a great economic power has induced significant shifts in patterns of world trade. As trading partners, advanced economies have faced rising import competition from China. Initially, the competition was concentrated in low-tech manufacturing industries, but has been shifting towards more technology-intensive industries, such as computer equipments and electronic computers (Figure 1). This trend has spurred a growing concern that rising import competition from China may undermine the United States' position as the world's innovation hub, in addition to impacting the U.S. labor market (Bernard et al., 2006; Autor et al., 2013; Autor et al., 2014; Acemoglu et al., 2016), and U.S. politics (Autor et al., 2016b, Che et al., 2016) adversely.

Figure 1: Chinese imports as percent of U.S. consumption

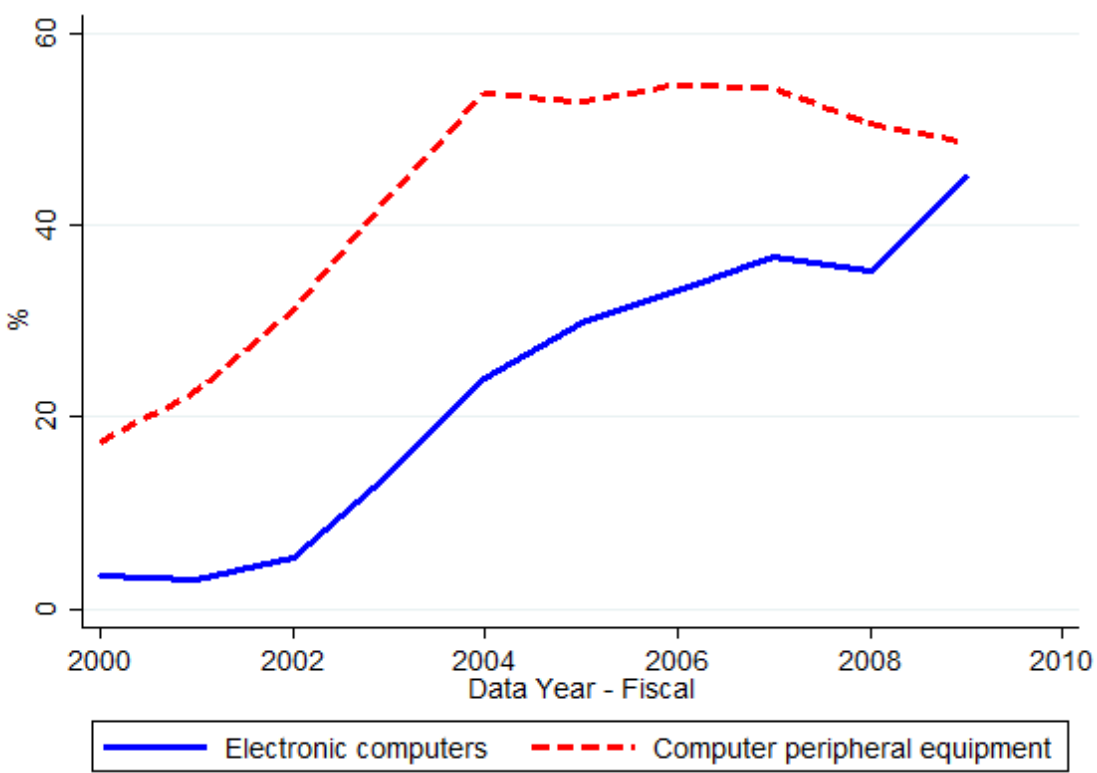

In this paper, we explore how import competition from China has affected U.S. firms' innovative activities. Theoretically, rising competition has ambiguous effects on R\&D incentives. On the one hand, some firms may invest more in R\&D to improve product quality and differentiability in order to rise above the competition. On the other hand, higher competition lowers the market share of domestic firms, thus causing firms to reduce R\&D investment. The net response of $R \& D$ investment depends on the relative strengths of these two effects. For instance, Aghion et al. (2005) identify an inverted-U relationship between market competition and innovation incentives. Even within the same industry, firms with different initial market powers respond heterogeneously to rising import competition. 
Guided by the theory, this paper focuses on estimating the reallocation effects of Chinese import competition on R\&D investment in the U.S. Using Compustat firm-level data, we find a large and positive reallocation effect of import competition on firm R\&D expenditures. Specifically, import competition induces the reallocation of R\&D expenditures towards more productive firms and more profitable firms. This reallocation effect exists in addition to the negative average effect on R\&D, as is also identified in Autor et al. (2016a). In aggregate, the positive reallocation effect is large enough to offset the negative average effect on $R \& D$ by U.S. firms. Correspondingly, there is no evidence that import competition reduces R\&D expenditures at industry level.

The identification strategy is similar to that in Autor et al. (2013), where cross-industry variations in Chinese imports are exploited. Import competition from China is measured by the ratio of Chinese imports to total U.S. consumption in each four-digit SIC industry. To correct for potential endogeneity concerns, we use Chinese exports to another eight high-income countries to instrument Chinese imports in the U.S. The impact of rising import competition is identified by regressing five-year changes of log R\&D expenditure by U.S. public firms on five-year changes of import competition, controlling for firm-specific characteristics, industry- and year- fixed effects.

Before exploring the reallocation effect, we confirm the average negative effect of Chinese imports on firm-level R\&D presented in Autor et al. (2016a). On average, firms reduce R\&D investment when they belong to industries that are exposed to more import competition from China. A 10 percentage point increase in import competition leads to a 6 percent drop in R\&D expenditures, on average. However, it is worth noting that, due to data limitation, import competition is measured at the industry level. As a result, the effects of import competition estimated in the literature are usually average effects and suffer from two shortcomings. First, the average effect masks differential impact or reallocation effect among firms within an industry. Second, the average effect does not provide information about the impact on aggregate $R \& D$ investment, because all firms are weighted equally, regardless of size.

We overcome those issues and contribute to the literature in three aspects. First, we estimate the within-industry reallocation effect of import competition using firm-level data. We find that import competition induces the reallocation of $R \& D$ towards firms that are more productive and firms that have more initial market power. This reallocation effect is large enough to offset the average negative effect when we aggregate the impact of import competition on all firms in the sample.

(C)International Monetary Fund. Not for Redistribution 
Second, we take the analysis to the industry level by aggregating firm-level R\&D investment in each SIC industry and repeat the analysis. The results suggest that import competition does not reduce industry-level R\&D expenditures. On the contrary, our analysis using employment data suggests that demand for researchers increases as a result of rising import competition, as evidenced by the higher employment shares and wages of researchers.

Third, we shift from examining firm-level R\&D expenditure data to analyzing researcher allocation in the population census. By matching import competition and employment of researchers in each industry, we can observe $\mathrm{R} \& \mathrm{D}$ allocation through the lens of the labor market. Indeed, we find evidence that rising import competition in manufacturing industries speeds up the structural transformation. In particular, researchers are reallocated from affected manufacturing industries to three service industries: business and repair services, financial services and personal services.

Our paper relates to several strands of literature. Regarding the trade literature, we find that trade with low-wage countries improves the allocative efficiency of innovative inputs. It complements the existing literature on trade and its impact on the reallocation of production (e.g., Melitz, 2003, Melitz and Redding, 2013).

The paper contributes to the sparse literature on import competition from China and its impact on U.S. innovation. One closely related paper is Autor et al. (2016a), which shows a reduction in innovative activities by U.S. public firms due to import competition from China. Those authors' results are based on an average effect specification similar to ours, except that they weigh each firm by its number of patents. Our paper extends their results on average effect, and focuses on whether import competition has induced the reallocation of R\&D resources. We find evidence for import competition's inducement of both withinindustry and across-industry reallocations. Our findings on reallocation among U.S. firms echo the reallocation effects among European firms in Bloom et al. (2016).

More generally, the study is connected to the broad literature on competition and innovation. Despite a large theoretical literature (e.g., Aghion et al., 2005), a major empirical challenge is finding external shocks to identify the causal impact of competition on innovation. Our paper extends this work by combining China's trade growth with firms' initial market powers to confirm the inverted-U relationship between market competition on innovation.

Finally, for labor economics, we use the U.S. population census to study the allocation of researchers across different industries. The novel use of researcher information can help 
address the concerns arising from Compustat's sole inclusion of public firms. Looking at researchers by industry, we find that import competition actually stimulates the employment of researchers in the affected industries. This evidence suggests that import competition mobilizes researchers from less efficient incumbent firms to younger private companies in the industry. Some displaced researchers also move to booming service industries, contributing to the ongoing structural transformation in the U.S.

The rest of the paper is organized as follows. Section II details the empirical modeling strategy. In Section III, we describe our data sources and provide summary statistics on key variables. Section IV presents the specification for the average effect and the empirical results. Section V explores heterogeneity across firms within each industry, and identifies the reallocation of $R \& D$ towards more productive firms and more profitable firms. In Section VI we discuss the findings, and Section VII concludes.

\section{EMPIRICAL Strategy}

In this section, we detail the methods for measuring import competition from China and the identification strategy. Due to a lack of information about firm-level import competition, we exploit industry-level variations in imports from China. To address potential endogeneity concerns, we follow Autor et al. (2013) and instrument Chinese import competition in the U.S. by those across eight other high-income countries.

\section{A. Measuring import competition}

We construct two measures of import competition from China at each SIC four-digit industry level. Both measures are similar to the ones used in Bloom et al. (2016), where Chinese imports are normalized by apparent consumption (domestic production less exports plus imports) or by domestic production. The specific definitions of both measures are as follows.

$$
\begin{aligned}
& \text { Import Competition } 1_{i, t}^{U S}=\frac{\text { Trade Flow }}{\text { China } \rightarrow U S} \\
& \text { Import Competition } 2_{i, t}^{U S}=\frac{\text { Trade Flow }_{i, t}^{\text {China } \rightarrow U S}}{\text { Value Added }{ }_{i, t}^{U S}}
\end{aligned}
$$

where Consumption ${ }_{i, t}^{U S}=$ Value $_{\text {Added }}^{U S}-$ Export $_{i, t}^{U S}+$ Import $_{i, t}^{U S} ; i$ denotes industry and $t$ is year (1995 to 2009). 
Increasing import competition may be caused by domestic productivity shocks or demand shocks, and those shocks can directly affect firms' R\&D incentives. As a result, simple OLS analysis will yield biased results. To address such endogeneity concerns, we follow Autor et al. (2013), instrumenting Chinese import competition in the U.S. by those in the other eight high income countries, including Denmark, Finland, Germany, Japan, New Zealand, Spain and Switzerland. The IV strategy is valid under the assumption that potential productivity or demand shocks in the U.S. are uncorrelated with those in other high-income countries. Anecdotally, increases in Chinese imports to the U.S. are mostly driven by China's growing productivity and opening up to trade instead of decreasing productivity or demand in highincome countries. The instruments are defined below.

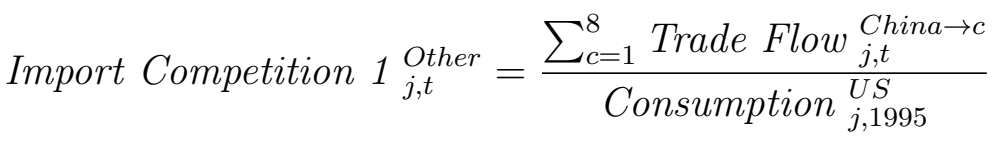

$$
\begin{aligned}
& \text { Import Competition 2 }{ }_{j, t}^{\text {Other }}=\frac{\sum_{c=1}^{8} \text { Trade Flow }}{\text { Vhina } \rightarrow c}
\end{aligned}
$$

where $c$ is the index for each of the eight advanced economies. Note that we have made the denominator consumption (or value added) in the U.S. in 1995 to eliminate concerns regarding the endogeneity of the instrumental variable.

\section{B. Estimating average effect}

In the first specification, we estimate how changes in firm-level R\&D investment are affected by changes in import competition. We look at five-year changes in R\&D expenditures and import competition. In addition to industry and year fixed effects, we control for fiveyear lags of key firm characteristics, including log asset holdings, market-to-book ratio and dependence on external financing (measured by Kaplan-Zingales index). ${ }^{1}$ Lagged firm-level characteristics are controlled because they may affect firms' R\&D investments (see Cohen, 2010). The standard errors are clustered at the SIC three-digit industry level to control for serial correlation.

The baseline regression is:

$$
\begin{aligned}
\Delta \log (R \& D)_{j, t} & =\beta_{1} \cdot \Delta \text { Import Competition } \text { Co.t }_{i, t}^{U . S}+\delta_{i}+\omega_{t} \\
& +\beta_{2} \cdot \text { Firm-level controls }{ }_{j, t-5}+\epsilon_{j, t}
\end{aligned}
$$

\footnotetext{
${ }^{1}$ We control for SIC 3-digit industry trend because the firm-fixed effects have been absorbed by the five-year differencing.
}

(CInternational Monetary Fund. Not for Redistribution 
where $j$ is firm index, $i$ is the three-digit industry it operates in, and $t$ is the observation year. We instrument Import Competition ${ }_{i, t}^{U S}$ by Import Competition ${ }_{i, t}^{\text {Other }}$, as defined above. We use an overlapping (rolling) sample in our main specification to maximize the use of the data (e.g., 2005-2000 and 2004-1999). The results using a non-overlapping sample are similar to those with an overlapping sample, and are included as robustness checks in the Appendix.

\section{Within-industry reallocation}

In the second specification, we decompose the impact of import competition into an average effect and a reallocation effect. We use the classic shift-share analysis using the following specification.

$$
\begin{aligned}
\Delta \log (R \& D)_{j, t} & =\beta_{1} \cdot \Delta \text { Import Competition }{ }_{i, t}^{U . S .}+\beta_{3} \cdot X_{j, t-5} \\
& +\beta_{4} \cdot \Delta \text { Import Competition }{ }_{i, t}^{U . S .} \times X_{j, t-5} \\
& +\beta_{2} \cdot \text { Firm-level controls }{ }_{j, t-5}+\delta_{i}+\omega_{t}+\epsilon_{j, t}
\end{aligned}
$$

where $X_{j, t-5}$ is lagged productivity or markup of firm $j$. For easy interpretation, $X_{j, t-5}$ is always expressed in deviations from the industry mean. ${ }^{2}$

We choose to use productivity and markup to estimate within-industry reallocation based on theoretical considerations. First, we test reallocation by firm's TFP level and labor productivity, because opening up to trade would lead to reallocation towards more productive firms, as derived in Melitz (2003), Melitz and Redding (2013) and Aghion et al. (2017). The literature has mainly focused on the reallocation effect of exporting, and we test whether import competition has similar effects. Second, we empirically test the inverted U-shaped relationship between competition and innovation using the China shock. Following Aghion et al. (2005), we measure the competition level faced by a firm by its markup (i.e., the Lerner index). If the theory holds, we should observe a positive interaction term, suggesting firms with higher markups increase $R \& D$ to beat the competition and firms with lower markups reduce $R \& D$.

A natural set of instruments for the interaction terms is the interaction between each original

\footnotetext{
${ }^{2}$ We normalize each firm's productivity and markup by subtracting industry mean level and the difference is divided by the industry standard deviation. The transformed variable has a direct interpretation of number of standard deviations away from the industry mean.
} 
instrument and firm's productivity (or profit). ${ }^{3}$ The estimate for $\beta_{4}$ can be interpreted as reallocation within industry, since we controlled for industry fixed effects.

\section{DAta AND Measurement}

We combine data on bilateral trade flows and U.S. domestic production to construct measures of import competition. The bilateral trade flows between China and the high-income countries (including the U.S.) are obtained from Comtrade. ${ }^{4}$ We merge the trade data with U.S. manufacturing data by SIC industry code. ${ }^{5}$ Import competition, as defined in Equations (1) to (4), can be easily computed using industry-level trade and production data.

The firm-level variables come from the Compustat (North America). The database contains data items reported in public firms' annual financial reports. In our analysis, we use R\&D investment, sales, total asset, and industry codes, which are directly available from the database. Other firm characteristics, including the market-to-book ratio, dependence on external financing, TFP, and the Lerner index are computed using the variables in Compustat. ${ }^{6}$ For all variables, we winsorize the raw data to limit the influence of outliers. ${ }^{7}$ Firms that did not incur any R\&D expenditures from 1995-2009 are dropped from our sample.

Once we have industry-level import competition and firm-level characteristics, the last step is to merge the two data sources by industry code. Unfortunately, the SIC codes used in Compustat are slightly different from the standard SIC codes. Some four-digit industries are aggregated to three-digit levels. For consistency, we harmonize the SIC code with the ones used in Compustat, and use those as the industry categories in our empirical analysis.

\footnotetext{
${ }^{3}$ See Wooldridge (2002) p.122 for an example of using interaction terms in IV estimates.

${ }^{4}$ We downloaded trade data from 1995 to 2007 from David Dorn's website, and we extended that data to 2009 using data from Comtrade.

${ }^{5}$ The industry-level manufacturing data are downloaded from the NBER Manufacturing CES database. The mapping between SIC industries and HS codes in trade is available on David Dorn's website.

${ }^{6}$ The construction of these variables is included in the Appendix.

${ }^{7}$ For each year, variables that can be positive or negative are winsorized at 1 percent at each tail, while variables that only take nonnegative values (such as employment) are winsorized at top 1 percent level.
} 
Table 1: Summary Statistics of Key Variables

\begin{tabular}{lcccc}
\hline \multicolumn{1}{c}{ Variable } & Obs & Mean & Std. Dev. & P50 \\
\hline Total assets in mil. USD & 28799 & 1744.954 & 11626.4 & 87.469 \\
Sales (net) in mil. USD & 28800 & 1547.598 & 9442.648 & 69.263 \\
R\&D expense in mil. USD & 28800 & 72.714 & 413.28 & 6.611 \\
R\&D expense/sales & 27452 & 2.512 & 15.698 & .081 \\
Employment (thousands) & 28800 & 4.867 & 19.6 & .332 \\
Market-to-book ratio & 24549 & 3.634 & 7.009 & 1.856 \\
Kaplan-Zingales index & 24176 & .922 & 3.144 & .565 \\
\hline Imp. Comp.1, US & 1503 & .078 & .145 & .02 \\
Five-year change in Imp. Comp.1, US & 710 & .031 & .087 & .011 \\
\hline \hline
\end{tabular}

In Table 1, we present summary statistics of key firm-level variables (top portion) and industry-level import competition (bottom portion). Looking at the median level of sales and employment, we can see the public companies in our sample are quite large as measured by size. The average employment size is 5,884 and the average net sales is $\$ 2$ billion. The distribution is also right-skewed as median employment and median sales are much smaller than the average levels. Our data winsorization can reduce the influence of the extreme values.

The bottom portion of the table lists import competition by industry and the changes in import competition over time. The large standard deviation of import competition level reflects significant variations across industries and across time, which are needed for the identification. The five-year changes in import competition also display large variations and small median levels, suggesting that rising import competition is concentrated in a few industries. 
Table 2: Top Five Industries by Increase in Import

Competition: 1997-2007

\begin{tabular}{|c|c|}
\hline Four-Digit Industry & $\Delta$ in Imp. Comp. \\
\hline Printing trades, machinery \& equipment & .69 \\
\hline Computer peripheral equipment & .47 \\
\hline Electronic computers & .36 \\
\hline Optical instruments \& lenses & .32 \\
\hline Games, toys \& children's vehicles & .32 \\
\hline
\end{tabular}

Which industries are most affected by import competition? We list the top five industries that experienced the largest rise in import competition in Table 2. Note that the top four out of five are technically advanced industries. Textile manufacturing and shoe-making industries are excluded because we drop firms with no R\&D investment. The most affected industry is printing trades machinery and equipment, which experienced a 69 percentage point increase in Chinese imports as a share of total consumption.

\section{Firm-LeVel Results}

In this section, we use firm-level data from Compustat to estimate the reallocation effect of import competition on $\mathrm{R} \& \mathrm{D}$, in addition to confirming the negative average effect identified in Autor et al. (2016a). The two effects are then summed up to measure the aggregate impact of Chinese imports on US manufacturing R\&D expenditures. The reallocation effects appear to be almost large enough to offset the negative average effect.

\section{A. Average effects}

Table 3 presents our key results: Firms in industries more exposed to Chinese import competition reduce $R \& D$ investment, on average. Each column in the table uses five-year changes in $\log \mathrm{R} \& \mathrm{D}$ expenditure as the dependent variable. ${ }^{8}$ We present simple OLS regression results in column (1) and (2), and instrumental regression results in columns (3) through (6). The first-stage F statistics suggest that the instrument is strong.

\footnotetext{
${ }^{8}$ The results are similar if we use the second measure of import competition, as well as three-year and five-year changes. The robustness check results are included in the Appendix.
} 
When comparing columns (3) and (4) with columns (1) and (2), we find that coefficient estimates from the IV regressions are larger in magnitude. This is because the industries facing more import competition may also experience positive demand shocks (booming industries). And so the OLS results would underestimate the negative effect of import competition. The magnitude and significance of $\triangle I m p . C o m p .1, U S$ are robust to including firm-level controls. We choose the estimates in column (4) as our baseline results for average effect.

In column (5), we restrict the sample to high-tech industries to remove the effect of sporadic R\&D investment by low-tech firms. The coefficient on import competition is slightly larger. Since firms enter and exit the Compustat sample, we restrict the sample to a balanced panel of firms in column (6). The impact of import competition increases further.

Table 3: Average Effects of Import Competition (Measure 1)

\begin{tabular}{|c|c|c|c|c|c|c|}
\hline & \multicolumn{2}{|c|}{ OLS } & \multicolumn{4}{|c|}{ 2SLS } \\
\hline & $\begin{array}{l}(1) \\
\text { All }\end{array}$ & $\begin{array}{l}(2) \\
\text { All }\end{array}$ & $\begin{array}{l}(3) \\
\text { All }\end{array}$ & $\begin{array}{l}\text { (4) } \\
\text { All }\end{array}$ & $\begin{array}{c}(5) \\
\text { High-tech }\end{array}$ & $\begin{array}{c}(6) \\
\text { Balanced Panel }\end{array}$ \\
\hline$\Delta$ Imp. Comp.1,US & $\begin{array}{c}-0.590^{* *} \\
(0.229)\end{array}$ & $\begin{array}{c}-0.590^{* * *} \\
(0.196)\end{array}$ & $\begin{array}{c}-0.618^{* *} \\
(0.245)\end{array}$ & $\begin{array}{c}-0.640^{* * *} \\
(0.238)\end{array}$ & $\begin{array}{c}-0.730^{* * *} \\
(0.267)\end{array}$ & $\begin{array}{c}-0.734^{* * *} \\
(0.236)\end{array}$ \\
\hline L5.Log asset & & $\begin{array}{c}0.009 \\
(0.008)\end{array}$ & & $\begin{array}{c}0.009 \\
(0.008)\end{array}$ & $\begin{array}{c}0.008 \\
(0.007)\end{array}$ & $\begin{array}{c}0.004 \\
(0.009)\end{array}$ \\
\hline L5.Market-to-book ratio & & $\begin{array}{l}0.010^{*} \\
(0.006)\end{array}$ & & $\begin{array}{l}0.010^{*} \\
(0.006)\end{array}$ & $\begin{array}{c}0.010 \\
(0.006)\end{array}$ & $\begin{array}{l}0.009^{*} \\
(0.005)\end{array}$ \\
\hline L5.KZ index & & $\begin{array}{c}-0.020^{* * *} \\
(0.005)\end{array}$ & & $\begin{array}{c}-0.020^{* * *} \\
(0.005)\end{array}$ & $\begin{array}{c}-0.021^{* * *} \\
(0.005)\end{array}$ & $\begin{array}{c}-0.018^{* * *} \\
(0.006)\end{array}$ \\
\hline $\begin{array}{l}\text { First-stage F statistic } \\
\mathrm{N}\end{array}$ & 13209 & 11230 & $\begin{array}{l}17.634 \\
13209\end{array}$ & $\begin{array}{l}16.337 \\
11230\end{array}$ & $\begin{array}{l}16.254 \\
9135\end{array}$ & $\begin{array}{c}15.101 \\
9163\end{array}$ \\
\hline
\end{tabular}

Note: The dependent variable is the five-year change in $\log (\mathrm{R} \& \mathrm{D})$ in all columns. The sample includes U.S. manufacturing firms in Compustat from 1995 to 2009. Industry- and year- fixed effects are controlled, and standard errors are clustered by industry. The first-stage F statistics of the 2SLS are reported.

In our baseline results (column 4), a 10 percentage point increase in industry-level import competition (i.e. the share of U.S. consumption imported from China) would lead to a 6.4 percent drop in R\&D investment, on average. The impact of import competition on R\&D expenditure by high-tech firms is bigger, with a 10 percent increase in import competition leading to a 7.3 percent decrease in R\&D expenditures on average. For firms in the balanced panel, import competition has a similar effect. 


\section{B. Induced reallocation within industry}

The estimated negative average effect masks heterogeneity among firms within the same industry. Import competition may have a differential impact on a firm, and thus can lead to the reallocation of $R \& D$ resources across firms in the same industry. Based on existing trade theory and firm $R \& D$ investment, we test the reallocation of $R \& D$ across two dimensions: productivity (measured by TFP and labor productivity) and market powers (measured by Lerner's index).

Using Equation 6, we empirically estimate the differential effect of import competition on firms with higher TFP, firms with higher labor productivity, and firms with higher profit margins. For consistency, we control for the same firm characteristics and fixed effects as in Table 3, column (4). The estimation results are presented in Tables 4,5 , and $6 .^{9}$

In terms of TFP, Table 4 suggests that more productive firms were shielded from import competition from China. In column (1), we copy the baseline average results from Table 3 for comparison. ${ }^{10}$ In column (2), we control for a firm's TFP deviation from the industry mean, with a five-year lag. The positive and significant coefficient suggests that firms with higher TFP tend to invest more in R\&D. In column (3), we estimate the reallocation effect by including the interaction between changes in import competition and lagged firm-level TFP. The interaction term captures the reallocation effect of import competition on a firm's R\&D spending.

The coefficient on the interaction term (column 3) is statistically significant and large in magnitude. For a U.S. firm whose TFP is 1 standard deviation above the industry mean, a 10 percentage point rise in import competition would lead to a 6.8 percent additional increase in $\mathrm{R} \& \mathrm{D}$. The magnitude of the reallocation effect is large enough to reverse the negative average effect, suggesting that firms with high TFP are not adversely affected by imports from China.

\footnotetext{
${ }^{9} \mathrm{As}$ a robustness check, we also control for changes in the share of foreign sales at the firm level. This is to address the concern that exporting to the Chinese market may confound the identified average effects and reallocation effects, as shown in Ahn and Duval (2017). The robustness check results are presented in Table $\mathrm{C} 7$ and Table C8, where the average and reallocation effects remain.

10 Note that the same firm characteristics and fixed effects are controlled here but not presented for conciseness purposes.
} 
Table 4: Reallocation of R\&D Towards High-TFP Firms

\begin{tabular}{lccc}
\hline \hline & $(1)$ & $(2)$ & $(3)$ \\
& $\Delta \log \mathrm{R} \& \mathrm{D}$ & $\Delta \log \mathrm{R} \& \mathrm{D}$ & $\Delta \log \mathrm{R} \& \mathrm{D}$ \\
\hline$\Delta$ Imp. Comp.1,US & $-0.640^{* * *}$ & $-0.499^{* * *}$ & $-0.584^{* * *}$ \\
& $(0.238)$ & $(0.188)$ & $(0.197)$ \\
L5.TFP (Olley-Pakes) & & $0.126^{* * *}$ & $0.105^{* * *}$ \\
& & $(0.035)$ & $(0.033)$ \\
$\Delta$ Imp. Comp $\times$ L5.TFP & & $0.683^{* *}$ \\
& & & $(0.270)$ \\
\hline First-stage F statistic & 16.337 & 14.911 & 7.609 \\
$\mathrm{~N}$ & 11230 & 8146 & 8146 \\
\hline \hline Standard errors in parentheses & & \\
${ }^{*} p<0.10,{ }^{* *} p<0.05,{ }^{* * *} p<0.01$ &
\end{tabular}

Note: We control for the same firm-level variables as in the previous table, including lagged log assets, market-to-book ratio and $\mathrm{KZ}$ index (dependence on external financing). Industry fixed effects and year effects are controlled, and standard errors are clustered by industry.

We use labor productivity, defined as value added per employee, as an alternative measure of firm productivity. Then, we reestimate Equation 6 and report the coefficient estimates in Table 5. The qualitative results are similar to the ones using firm TFP: More productive firms do more $R \& D$, and import competition induces $R \& D$ to be reallocated towards more productive firms. The coefficient of the interaction term is larger in magnitude, probably because labor productivity is a more general measure of productivity.

Table 5: Reallocation of R\&D Towards More Productive Firms

\begin{tabular}{lccc}
\hline \hline & $(1)$ & $(2)$ & $(3)$ \\
& $\Delta \log \mathrm{R} \& \mathrm{D}$ & $\Delta \log \mathrm{R} \& \mathrm{D}$ & $\Delta \log \mathrm{R} \& \mathrm{D}$ \\
\hline$\Delta$ Imp. Comp.1,US & $-0.640^{* * *}$ & $-0.479^{* *}$ & $-0.556^{* * *}$ \\
& $(0.238)$ & $(0.191)$ & $(0.198)$ \\
L5.Labor productivity & & $0.109^{* * *}$ & $0.075^{*}$ \\
& & $(0.041)$ & $(0.038)$ \\
$\Delta$ Imp. Comp $\times$ L5.Labor productivity & & & $1.116^{* *}$ \\
& & & $(0.483)$ \\
\hline First-stage F statistic & 16.337 & 14.918 & 7.663 \\
$\mathrm{~N}$ & 11230 & 8146 & 8146 \\
\hline \hline
\end{tabular}

Standard errors in parentheses

${ }^{*} p<0.10,{ }^{* *} p<0.05,{ }^{* * *} p<0.01$

Note: We control for the same firm-level variables as in the previous table, including lagged log assets, market-to-book ratio and book leverage. Industry fixed effects and year effects are controlled, and standard errors are clustered by industry. 
Last, we explore what happens when profit margins are interacted with import competition. According to Aghion et al. (2005), innovation by firms depends on competition level. Companies would increase $R \& D$ to rise above competition only if their original levels of competition are low. Following the literature, we measure competition level by the Lerner index, that is, the ratio of operating profit over sales. A higher Lerner index means a higher profit margin and lower level of competition. The higher profit margin may result from more differentiated products, and hence can help the company weather Chinese competition better.

Our results in Table 6 confirm that import competition induces R\&D to be reallocated to firms with higher initial market powers (measured by profit margin). In column (2), we show that firms with higher profit margins increase R\&D investment more. In column (3), the interaction term is positive and significant, suggesting that firms facing initially low competition (proxied by higher profit margin) are not adversely affected by import competition. Instead, they would increase $R \& D$ investment and differentiate their products further to maintain market share. On the other hand, firms facing high initial competition reduce their $R \& D$ expenditures, as evidenced by the large and highly significant coefficient on $\Delta$ Imp.Comp.1,US. The results are consistent with the inverted-U relationship identified in Aghion et al. (2005).

Table 6: Reallocation of R\&D Towards High-Markup Firms

\begin{tabular}{lccc}
\hline \hline & $(1)$ & $(2)$ & $(3)$ \\
& $\Delta \log R \& D$ & $\Delta \log R \& D$ & $\Delta \log R \& D$ \\
\hline$\Delta$ Imp. Comp.1,US & $-0.640^{* * *}$ & $-0.613^{* * *}$ & $-0.672^{* * *}$ \\
& $(0.238)$ & $(0.210)$ & $(0.222)$ \\
L5.Profit margin & & $0.238^{* * *}$ & $0.215^{* * *}$ \\
& & $(0.028)$ & $(0.029)$ \\
$\Delta$ Imp. Comp $\times$ L5.Profit margin & & & $0.656^{* * *}$ \\
& & & $(0.227)$ \\
\hline First-stage F statistic & 16.337 & 15.937 & 7.936 \\
$\mathrm{~N}$ & 11230 & 9628 & 9628 \\
\hline \hline
\end{tabular}

Standard errors in parentheses

${ }^{*} p<0.10,{ }^{* *} p<0.05,{ }^{* * *} p<0.01$

Note: We control for the same firm-level variables as in the previous table, including lagged log assets, market-to-book ratio and dependence on external financing (KZ index). Industry fixed effects and year effects are controlled, and standard errors are clustered by industry. 


\section{Aggregating average and reallocation effects}

We have identified both a positive reallocation effect and a negative average effect of import competition from China. What is the aggregate impact of import competition on R\&D expenditures in U.S. manufacturing industries?

To answer this question, we use two approaches. First, we adopt a decomposition approach to derive the aggregate changes in $\mathrm{R} \& \mathrm{D}$ investment due to Chinese import competition, using the estimates of the average and the reallocation effect of import competition. Second, we estimate the impact of import competition on industry-level R\&D activity using regressions. In this section we present the results from the decomposition method, which is calculated using firm-level results. In Section 5.1 we show the results on industry-level R\&D expenditures.

The percentage change in U.S. R\&D spending due to Chinese import competition can be expressed as a function of regression coefficients and firms' initial R\&D expenditures: ${ }^{11}$

$$
\begin{aligned}
\% \Delta & \text { in } R \mathscr{E} D^{\mathrm{China}}=\frac{1}{N} \sum_{j=1}^{N} \beta_{1, a v g} \cdot \Delta \operatorname{Imp} \operatorname{Comp}_{i, t} \\
+ & \frac{1}{N} \sum_{j=1}^{N}\left(\beta_{1, T F P} \cdot+\beta_{4, T F P} \cdot T F P_{j, t-5}\right) \cdot \Delta \operatorname{Imp} \operatorname{Comp}_{i, t} \cdot \frac{\left(R \& D_{j, t-5}-\overline{R \& D}_{t-5}\right)}{R \& D_{t-5}}
\end{aligned}
$$

where $j$ is the firm index, $i$ is the industry index, $N$ is the number of firms, and $T F P_{j}$ is expressed as standard deviations from the industry mean. We use the coefficients estimated before: $\beta_{1, a v g}=-0.640$ in Table $3 ; \beta_{1, T F P}=-0.584$ and $\beta_{4, T F P}=0.683$ from Table 4 .

The decomposition in Equation 7 is similar to the one in Bloom et al. (2016). The change of overall $\mathrm{R} \& \mathrm{D}$ expenditure due to Chinese import competition $\left(\% \Delta R \& D^{\text {China }}\right)$ is the sum of two components: the average effect of import competition and the reallocation effect. In aggregating the reallocation effect, each firm is weighted by the deviation of its $R \& D$ expenditure from the overall mean level of $R \& D$ in the initial year. Since more productive firms tend to conduct more R\&D activities, the weight on more productive firms is larger than that on less productive firms. As a result, the reallocation effect is positive, and could offset, or even reverse, the negative average effect.

Our empirical results confirm that the reallocation effect is positive and sizable. For each

\footnotetext{
${ }^{11}$ The derivation of this estimate is detailed in the Appendix. For simplicity, we ignore firm entry and exit.
} 
year, we compute the aggregate impact of import competition as the sum of the average effect and the reallocation effect as specified in Equation 7. The total effect and its decomposition from 2000-2007 are presented in Figure 2. ${ }^{12}$ The reallocation effect is comparable in size to the average effect. Total effects are still negative but very small, because reallocation effect can offset 57 percent (in 2007) to 90 percent (in 2005) of the average effect.

Figure 2: Changes in Total R\&D Expenditure due to Chinese Competition (TFP)

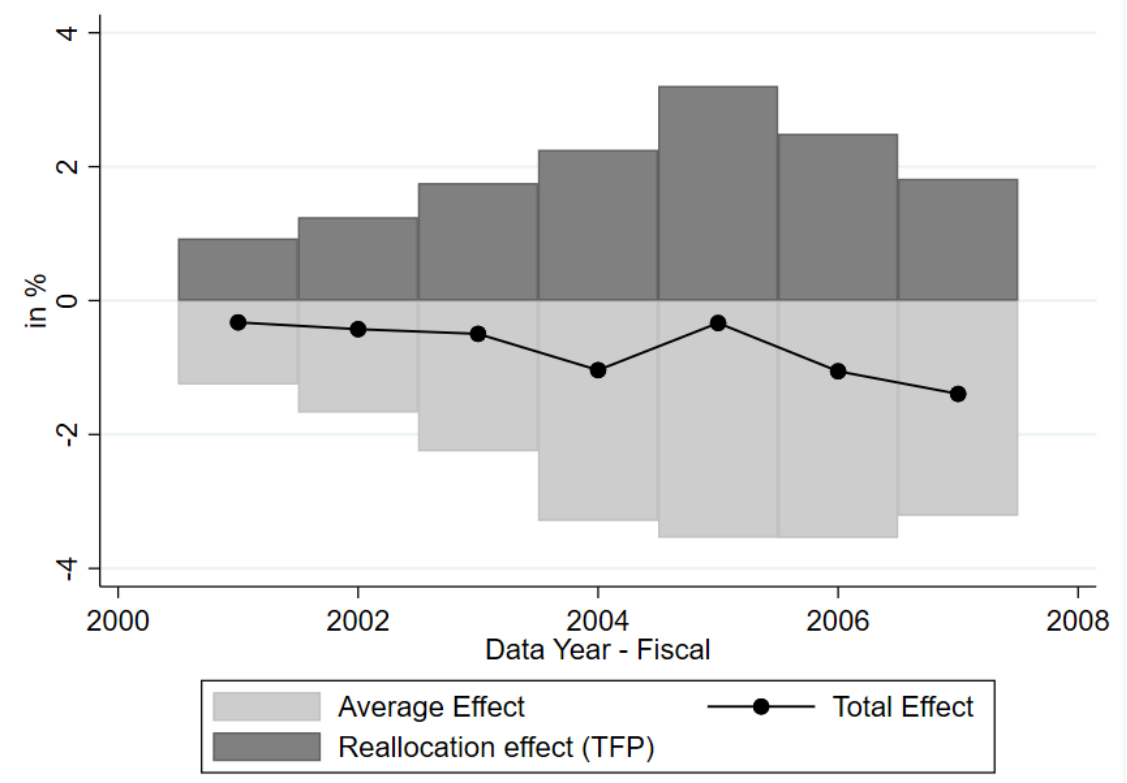

\section{INDUSTRY-LeVel Results}

In this section, we take the analysis to the industry level and show that industry-level R\&D expenditures and research inputs are not adversely affected by import competition.

We use two data sources to measure industry-level $R \& D$ input. First, we aggregate the firm-level R\&D expenditure in each SIC industry to obtain a consistent measure of industrylevel R\&D spending. The econometric model used here will be similar to the average-effect specification in the firm-level analysis. Second, we use the U.S. Decennial Census in 2000 and American Community Survey since 2006 to study the allocation of researchers across industries.

Compared to the Compustat, which only include public firms, the population census data

\footnotetext{
${ }^{12}$ The decomposition starts in 2000 due to five-year lags. Decomposition from 2008 and 2009 are not included because of anomalies that occur during the financial crisis.
} 
include researchers in all companies, private and public. This can alleviate, to some degree, the concern that $\mathrm{R} \& \mathrm{D}$ expenditures in private firms are excluded from Compustat. In addition, we can project the industry-level import competition to the occupation-level. Assuming researchers in each Science and Engineering occupation move across industries, we can identify whether import competition has induced researchers to be reallocated from manufacturing to certain service industries.

\section{A. Effect of import competition on industry-level R\&D}

We compute industry-level R\&D expenditures by summing up the R\&D expenditures of Compustat firms in each SIC industry. To eliminate firm entry and exit bias, we restrict the sample to a balanced panel of Compustat firms from 1997-2009. To be consistent with firm-level analysis, we also control for log assets, market-to-book ratio, and book leverage, evaluated at the median level in each industry. In Table 7, we report and compare the OLS estimates and the 2SLS estimates.

Our results in Table 7 suggest that import competition does not adversely affect industrylevel R\&D expenditure among the balanced panel of Compustat firms. Compared to the negative firm-level results in column (6) of Table 3 based the same balanced panel, the industry-level results suggest that $\mathrm{R} \& \mathrm{D}$ must have been reallocated towards more productive (or more profitable) firms. We consider this aggregate effect more relevant to policy-related discussions.

Table 7: Impact of Import Competition on Industry R\&D

\begin{tabular}{|c|c|c|c|c|c|c|}
\hline \multirow[b]{2}{*}{$\Delta$ Imp. Comp.1 } & \multicolumn{2}{|c|}{ OLS } & \multicolumn{2}{|c|}{$2 \mathrm{SLS}$} & \multicolumn{2}{|c|}{ 2SLS (SIC3 FE) } \\
\hline & $\begin{array}{l}-0.068 \\
(0.230)\end{array}$ & $\begin{array}{c}-0.176 \\
(0.233)\end{array}$ & $\begin{array}{c}0.179 \\
(0.399)\end{array}$ & $\begin{array}{c}-0.088 \\
(0.412)\end{array}$ & $\begin{array}{c}0.105 \\
(0.427)\end{array}$ & $\begin{array}{c}0.031 \\
(0.427)\end{array}$ \\
\hline L5.Log(total assets) & & $\begin{array}{c}-0.044^{* * *} \\
(0.009)\end{array}$ & & $\begin{array}{c}-0.044^{* * *} \\
(0.009)\end{array}$ & & $\begin{array}{c}-0.052^{* * *} \\
(0.013)\end{array}$ \\
\hline L5.Median market to book ratio & & $\begin{array}{c}0.058^{* * *} \\
(0.017)\end{array}$ & & $\begin{array}{c}0.058^{* * *} \\
(0.017)\end{array}$ & & $\begin{array}{l}0.031^{*} \\
(0.018)\end{array}$ \\
\hline L5.Median book leverage & & $\begin{array}{c}-0.284^{* *} \\
(0.123)\end{array}$ & & $\begin{array}{c}-0.276^{* *} \\
(0.126)\end{array}$ & & $\begin{array}{c}-0.449^{* *} \\
(0.185)\end{array}$ \\
\hline First-stage F statistic & & & 674.377 & 623.438 & 654.948 & 642.348 \\
\hline $\mathrm{N}$ & 1363 & 1329 & 1363 & 1329 & 1361 & 1327 \\
\hline $\begin{array}{l}\text { Standard errors in parentheses } \\
{ }^{*} p<0.10,{ }^{* *} p<0.05,{ }^{* * *} p<0.01\end{array}$ & & & & & & \\
\hline
\end{tabular}


Among public firms, import competition does not have adverse effect on industry-level R\&D investment. How would the result change if we included research input in private firms and other institutions? To tackle this question, we turn to the population census data and look at allocation of researchers across industries. Specifically, we merge U.S. population census data in 2000 and 2006-2012 with industry-level import competition measures in 1997 and 2003-2009, respectively. We choose a three-year lag to account for the fact that it takes time for labor to move from one industry to another due to rising import competition. Industry codes used for the merge are IND1990 in the population census, and they are coarser than the four-digit SIC codes.

Researchers in our analysis are defined as prime age workers (employed full-time and aged between 25 to 65) who hold at least one college degree and work in a Science and Engineering (S\&E) occupation. Following the classification by the NSF, we identify 47 S\&E occupations: managers in science and engineering industries (two occupations), 10 computer and mathematical occupations, 15 architecture and engineering occupations, technicians (two occupations), and 16 life, physical and social science occupations.

We measure research intensity by computing the share of researchers among all workers in each industry. To explore if wages for researchers are affected by import competition, we also look at average wages for researchers. We estimate the following equation using both OLS and 2SLS, where $Y$ is either share of researchers or the average wage of researchers. The

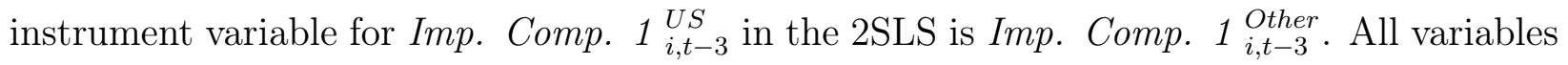
are constructed at the IND1990 industry level in the census.

$$
Y_{i, t}=\operatorname{Imp} . \text { Comp. } 1_{i, t-3}^{U S}+\delta_{i}+\gamma_{t}+\epsilon i, t
$$

Table 8 presents both the OLS estimates (columns 1 and 3) and 2SLS estimates (columns 2 and 4). Import competition appears to attract researchers to affected industries. A 10 percentage point increase in import competition would lead to a 1 percentage point increase in the researcher share. Given that the total share of researchers in employment is less than 5 percent, the magnitude of the positive effect is economically significant.

Wages of researchers also respond positively to rising import competition. A 10 percentage point increase in import competition leads to a 7 percent increase in wages paid to researchers. Combined with the positive effect on the researcher share, rising import competition leads to an increase in researchers' total payroll.

(C)International Monetary Fund. Not for Redistribution 
Compared to the insignificant effect on industry-level R\&D expenditures by public firms, we can infer that private companies in the U.S. may have stepped up their R\&D investment as less efficient incumbents scaled back their R\&D activities.

Table 8: Impact of Import Competition on Researchers (by Industry)

\begin{tabular}{lccccc}
\hline \hline & \multicolumn{2}{c}{ Researcher/Employment } & & \multicolumn{2}{c}{ Log wage } \\
\cline { 2 - 3 } \cline { 5 - 6 } & $(1)$ & $(2)$ & & $(3)$ & $(4)$ \\
\hline L3.Imp Comp.1,US & $0.082^{* * *}$ & $0.098^{* * *}$ & & $0.379^{* * *}$ & $0.680^{* * *}$ \\
& $(0.021)$ & $(0.032)$ & & $(0.080)$ & $(0.123)$ \\
\hline F statistic (K-P) & 552 & 360.926 & & 360.926 \\
$\mathrm{~N}$ & 552 & & 552 & 552 \\
\hline \hline
\end{tabular}

Standard errors in parentheses

${ }^{*} p<0.10,{ }^{* *} p<0.05,{ }^{* * *} p<0.01$

Note: Industry fixed effect and year effect are controlled. We merge U.S. population censuses $(2000,2006-2012)$ with industry-level import competition measures (1997, 2003-2009), respectively. Researchers are defined as college graduates working in $\mathrm{S} \& \mathrm{E}$ occupations.

\section{B. Reallocation of researchers towards service industries}

As import competition intensifies in some manufacturing industries, researchers can either move to other manufacturing industries, or go to service industries that require similar talents. Has import competition induced researchers to relocate from manufacturing to service industries? We explore that question using the following specification:

$$
\frac{\text { Number of researchers }}{s, o, t}=\beta_{s} \cdot \text { Import Competition }_{o, t-3}^{\text {China } \rightarrow U S}+\gamma_{o}+\mu_{t}+\epsilon_{s, o, t}
$$

where $s$ is one of the 9 service industries, $o$ is one of the 47 Science and Engineering occupations, and $t$ is the observation year. ${ }^{13}$

We estimate Equation 9 for each service industry $s$. The key independent variable here is the occupation-level import competition from China, and instrument Import Competition US with Import Competition $n_{o, t-3}^{\text {Other }}$. Both variables are constructed using industry-level import

\footnotetext{
${ }^{13}$ The nine service industries are: 1) transportation and other public utilities; 2) wholesale trade durables; 3) wholesale trade non-durables; 4) retail trade; 5) finance; 6) business and repair; 7) personal; 8) entertainment and recreation; and 9) professional services.
} 
competition and employment share as follows.

$$
\begin{aligned}
& \text { Import Competition } n_{o, t}^{\text {China } \rightarrow U S}=\sum_{j} s_{j, o, t} \cdot \text { Import Competition }_{j, t}^{\text {China } \rightarrow U S} \\
& \text { Import Competition }{ }_{o, t}^{\text {China } \rightarrow \text { Other }}=\sum_{j} s_{j, o, t} \cdot \text { Import Competition } \text { Imina } \rightarrow \text { Other }^{\text {Chin }}
\end{aligned}
$$

where $s_{j, o, t}=$ number of workers in industry $\mathrm{j}$, occupation o at time $\mathrm{t} /$ total number of workers in occupation o at time t.

In this specification, our underlying assumption is that researchers within each S\&E occupation only move across industries. By looking at the allocation of researchers within each S\&E occupation, we can see if import competition leads to higher concentrations of researchers in certain service industries. We estimate Equation 9 for each of the nine service industries, and all service industries as a whole. A positive sign on $\beta_{s}$ can be interpreted as the reallocation of researchers towards service industry $s$ due to rising import competition. The estimation results are presented in Table 9 . To be concise, we omit the results of insignificant service industries.

As shown in Table 9, research occupations more exposed to import competition witness a shift of researchers from manufacturing to three service industries, namely business and repair services, financial services and personal services. The reallocation to Business and Repair Services is the most significant and largest in magnitude. This is consistent with the boom in computer and data processing services that has been happening in the U.S. since 2000, especially after the financial crisis. In terms of magnitude, a one standard deviation increase in occupation-level import competition would lead to an 11.5 percentage point increase in the share of researchers working in business and repair services. Financial services and personal services also benefit from higher supply of researchers mobilized from import-struck manufacturing industries. 
Table 9: Researchers Move to Three Service Industries

\begin{tabular}{lccc}
\hline \hline & $(1)$ & $(2)$ & $(3)$ \\
& finance & business and repair & \begin{tabular}{c} 
personal \\
\hline L3.Imp Comp.1(Occ)
\end{tabular} \\
& $0.072^{*}$ & $0.115^{* *}$ & $0.111^{*}$ \\
& $(0.036)$ & $(0.047)$ & $(0.057)$ \\
\hline F statistic (K-P) & 1324.621 & 1324.621 & 1324.621 \\
$\mathrm{~N}$ & 341 & 341 & 341 \\
\hline \hline Standard errors in parentheses & & \\
${ }^{*} p<0.10,{ }^{* *} p<0.05,{ }^{* * *} p<0.01$ & &
\end{tabular}

Note: Occupation fixed effect and year effect are controlled. Only significant service industry results are presented. Researchers in service industries overall and other service industries not listed here are not affected.

\section{Discussion}

We identify significant reallocation of $R \& D$ expenditures across firms within an industry, where import competition intensifies. As $R \& D$ expenditures move towards more productive and more profitable firms, the negative average effect goes away when we aggregate the effects at the industry level or at the whole manufacturing-sector level.

The reallocation effect is explored along two dimensions based on existing theories. The first dimension is firm-level productivity. Recall that import competition has two competing effects on firms' R\&D incentives. Firms may scale back production (Tybout (2008)) and proportionally $R \& D$ investment if their market share shrinks due to intense competition. This channel is considered as the driving force for declining patenting activities in the U.S. in in Autor et al. (2016a). On the other hand, increasing R\&D investment enables firms to to differentiate their products and rise above the competition, as is shown in De Loecker (2011) and Hombert and Matray (2015). More productive firms are likely to have more differentiated products and higher capacity to innovate, and thus the second effect is likely to dominate. Our empirical results confirm the theoretical prediction that import competition leads to R\&D resources to be reallocated towards more productive firms. Such reallocation can be viewed as optimal investment decisions made by firms, and thus may not require any policy intervention.

Second, we incorporate the inverted U-shaped relationship in Aghion et al. (2005), and test if firms with more market power invest more in $R \& D$ to rise above the competition. We measure market power by Lerner index as in Aghion et al. (2005) and our results confirm the theory: Firms facing already high competition reduce R\&D as import competition intensifies, 
and the mobilized $R \& D$ resources are reallocated to firms with higher initial market powers.

In addition to counteracting the negative average effect, the reallocation effect can bring efficiency gains. The mechanism is similar to the theory in Melitz (2003), where opening to trade leads to the reallocation of production resources and revenues from less productive to more productive firms. The recent work by Aghion et al. (2017) provides theoretical and empirical evidence about the reallocation of innovative activities among French firms due to export shocks. Our study looks at import shocks and identifies the reallocation of R\&D investment from less to more productive firms. Provided that total R\&D investment does not drop, import-induced reallocation can improve aggregate R\&D efficiency. The efficiency gains in R\&D investment also relate to the productivity growth slowdown in the U.S. since mid-2000s. More efficient allocation of R\&D resources induced by import competition from 1995 to 2005 may have contributed to higher production efficiency during the period compared to that post-crisis (Cardarelli and Lusinyan (2015)).

Our results relate to the literature on the cleansing effect of negative shocks. As pointed out by Davis and Haltiwanger (1992) and Davis and Haltiwanger (1999), the reallocation of labor is accelerated after negative economic shocks. The reallocation can be productivityenhancing because the cost of reallocation is low during recessions (the cleansing effect). We find the cleansing effect on firms' innovative activities occurs in response to negative demand shocks. This effect is not only present among less productive firms within the same industry, it also mobilizes R\&D resources from stagnant manufacturing industries to booming service industries.

The manner in which trade with China affects the U.S. economy has been under heated discussion, among academics, as well as policy makers. Our analysis contributes to the discussion by evaluating the reallocation effect and comparing its magnitude to the negative average effect identified in previous literature (see Autor et al. (2013), Acemoglu et al. (2016), and Autor et al. (2016a)). Our use of population census data to study researcher allocation enables us to incorporate innovative activities in non-public firms, as well as in service industries. The novel approach of studying researchers reveals an overall positive effect of import competition on researchers' employment and wages. This finding adds to the sparse literature about trade and innovation from the labor market perspective.

Finally, we extend the focus from manufacturing industries to include R\&D in service industries. By analyzing researchers' industry choices, we find evidence that import competition 
in manufacturing induced skilled workers to move to three service industries, namely, business and repair services, personal services, and financial services. This is in line with the stylized fact that employment share in manufacturing has been declining, from 22 percent in 1980 to 8 percent in $2016 .{ }^{14}$ The existing literature on import competition has been mostly about the displacement of low-skilled workers engaged in routine tasks, as in Autor et al. (2013), Ebenstein et al. (2014), Autor et al. (2014), and Acemoglu et al. (2016). Our analysis provides empirical evidence that researchers, who are engaged in highly cognitive tasks, have also moved to service industries due to import competition.

\section{Conclusions}

Has import competition from China induced the reallocation of $R \& D$ expenditures across firms within manufacturing industries in the U.S.? Has the intensifying competition in manufacturing mobilized R\&D resources to be reallocated to certain service industries? In this paper, we have examined these questions using U.S. firm-level data and population census data. In particular, we look at how import competition has affected R\&D expenditures in U.S. public firms, and we leverage the detailed worker information in the population census to study the allocation of researchers. Our findings provide insights about R\&D resources at the firm-level, as well as at the industry level.

Our results identify reallocation both within and across industries. Our primary result is that import competition from China has led to R\&D reallocation across firms within an industry. R\&D expenditures appear to flow towards more productive firms and more profitable firms. This reallocation effect can reconcile the identified average negative effect on firm-level R\&D and the insignificant effect on industry-level R\&D expenditures. Second, our analysis of population census suggests that competition from Chinese imports have induced researchers in manufacturing to move towards three service industries, namely, business and repairs, finance, and personal services.

Our findings have key policy implications regarding import competition and U.S. innovation. At the industry level, import competition has no significant impact on R\&D expenditures among public firms. More intense competition has directed R\&D resources towards more productive and more profitable public firms, and potentially towards young private firms. Therefore, policy makers should not be overly concerned about import competition with regard to innovation and the U.S.'s future growth. In terms of labor market outcome, rising

\footnotetext{
${ }^{14}$ Figures come from Bureau of Labor Statistics.
} 
competition from Chinese imports has actually increased the demand for researchers, as evidenced by higher wages and employment of researchers in affected industries. This higher demand for high-skilled workers signifies the need to educate and supply more well-trained engineers and scientists domestically.

Several further topics of inquiry are left for future research. First, we would like to test whether import competition has encouraged creative destruction in the U.S. In the current analysis, we only have data for publicly traded firms in Compustat. If one were to have access to census data on all U.S. firms, one could test whether young private firms are innovating more as large incumbents lose market shares due to foreign competition. Second, since our analysis exploits variations at the industry level, it would be interesting to analyze import competition at more granular levels, such as product level or firm level. Our reallocation results suggest that there is substantial heterogeneity among firms within the industry. Ignoring the heterogeneity would yield misleading conclusions. Third, given the non-rivalrous nature of new technology, we can extend our focus from U.S. innovation to world innovation by incorporating innovation in China. A theoretical framework on world innovation could be constructed to complement the empirical analysis and provide welfare implications. 


\section{References}

Acemoglu, Daron, David Autor, David Dorn, Brendan Price, and Gordon Hanson, "Import Competition and the Great US Employment Sag of the 2000s," Journal of Labor Economics, 2016, 34, 141-198.

Aghion, Philippe, Antonin Bergeaud, Matthieu Lequien, and Marc Melitz, "The Impact of Export on Innovation: Theory and Evidence," Working Paper, 2017.

_ , Nicholas Bloom, Richard Blundell, Rachel Griffith, and Peter Howitt, "Competition and Innovation: An Inverted-U Relationship," The Quarterly Journal of Economics, 2005, 120(2), 701-728.

Ahn, JaeBin and Romain Duval, "Trading with China: Productivity Gains, Job Losses," IMF Working Paper WP/17/122, 2017.

Almeida, Heitor, Murillo Campello, and Michael Weisbach, "The Cash Flow Sensitivity of Cash," The Journal of Finance, 2004, 59(4), 1777-1804.

Autor, David, David Dorn, and Gordon Hanson, "The China Syndrome: Local Labor Market Effects of Import Competition in the United States," The American Economic Review, 2013, 103(6), 2121-68.

_ , _ , Gordon H. Hanson, Pian Shu, and Gary Pisano, "Foreign Competition and Domestic Innovation: Evidence from U.S. Patents," NBER Working Paper, 2016.

_ , _ , Gordon Hanson, and Jae Song, "Adjustment to Trade: Worker Level Evidence," The Quarterly Journal of Economics, 2014, 129 (4), 1799-1860.

_ , _ , _, and Kaveh Majlesi, "Importing Political Polarization? The Electoral Consequences of Rising Trade Exposure," NBER Working Paper, 2016.

Bernard, Andrew, Bradford Jensen, and Peter Schott, "Survival of the Best Fit: Exposure to Low-wage Countries and the (uneven) Growth of US Manufacturing Establishments," The Journal of International Economics, 2006, 68, 219-237.

Bloom, Nicholas, Mirko Draca, and John Van Reenen, "Trade Induced Technical Change? The Impact of Chinese Imports On Innovation, IT and Productivity," The Review of Economic Studies, 2016, 83(1), 87-117.

Cardarelli, Roberto and Lusine Lusinyan, "U.S. Total Factor Productivity Slowdown: Evidence from the U.S. States," IMF WP/15/116, 2015. 
Che, Yi, Yi Lu, Justin Pierce, Peter Schott, and Zhigang Tao, "Did Trade Liberalization with China Influence U.S.Elections?," NBER Working Paper, 2016.

Cohen, Wesley, "Fifty Years of Empirical Studies OF Innovative Acitivity and Performance," Handbook of the Economics of Innovation, 2010.

Datta, Sudip, Mai Iskandar-Datta, and Vivek Singh, "Product Market Power, Industry Structure, and Corporate Earnings Management," Journal of Banking $\& 3$ Finance, 2013, 37(8), $3273-3285$.

Davis, Steven and John Haltiwanger, "Gross Job Creation, Gross Job Destruction, and Employment Reallocation," The Quarterly Journal of Economics, 1992, 107(3), 819-863.

_ and _, "Gross Job Flows," Handbook of labor economics, 1999.

Ebenstein, Avraham, Ann Harrison, Margaret McMillan, and Shannon Phillips, "Estimating the Impact of Trade and Offshoring on American Workers Using the Current Population Surveys," Review of Economics and Statistics, 2014, 96 (4), 581-595.

Hombert, Johan and Adrien Matray, "Can Innovation Help U.S. Manufacturing Firms Escape Import Competition from China?," Working Paper, 2015.

İmrohoroğlu, Ayşe and Şelale Tüzel, "Firm-Level Productivity, Risk, and Return," Management Science, 2014, 60 (8), 2073-2090.

Kaplan, Steven N. and Luigi Zingales, "Do Investment-Cash Flow Sensitivities Provide Useful Measures of Financing Constraints?," Quarterly Journal of Economics, 1997, 112 (1), 169215.

Lerner, Abba P, "Economic Theory and Socialist Economy," The Review of Economic Studies, 1934, 2 (1), 51-61.

Loecker, Jan De, "Product Differentiation, Multiproduct Firms, and Estimating the Impact of Trade Liberalization on Productivity," Econometrica, 2011, 79 (5), 1407-1451.

Melitz, Marc J, "The Impact of Trade on Intra-industry Reallocations and Aggregate Industry Productivity," Econometrica, 2003, 71 (6), 1695-1725.

Melitz, Marc J. and Stephen J. Redding, "New Trade Models, New Welfare Implications," NBER Working Paper, 2013.

Olley, G. Steven and Ariel Pakes, "The Dynamics of Productivity in the Telecommunications Equipment Industry," Econometrica, 1996, 64 (6), 1263-1297. 
Tybout, James R., "Plant- and Firm-level Evidence on "New" Trade Theories," Handbook of International Trade, 2008.

Wooldridge, Jeffrey, Econometric Analysis of Cross-Section and Panel Data, The MIT Press, 2002. 


\section{A TFP measurement}

We follow Olley and Pakes (1996) and İmrohoroğlu and Tüzel (2014) to measure firm-level TFP using Compustat (North America) Database and NBER Manufacturing Database. We consider a two-factor production function, in which labor and capital are considered as production inputs, and value-added is considered as production output.

We first construct variables needed in the estimation procedure. Labor input is log total employment (EMP), capital input is log total net value of property, plant, and equipment (PPENT) in the previous year, and investment is log capital expenditure (CAPX). All the three items are from Compustat. Value-added is total sales (SALE) minus material, deflated by industry-level price deflator from the NBER Manufacturing Database. Material is computed as cost of goods sold (COGS) less total depreciation (DP) and labor expenses. If total staff expenses (XLR) is not missing in Compustat, the item is considered as labor expenses; otherwise, we use average industry annual payroll from the NBER Manufacturing Database multiplied by total employment (EMP) as total labor expenses.

Olley-Pakes method assumes that firms' production function is:

$$
y_{i t}=\beta_{0}+\beta_{l} l_{i t}+\beta_{k} k_{i t}+\omega_{i t}+\eta_{i t}
$$

in which $l_{i t}$ is labor input, $k_{i t}$ is capital input, and $\omega_{i t}$ is productivity. Simultaneity problem arises because firms make investment and production decisions based on $\omega_{i t}$. Firms can freely adjust their labor input, but have to conduct investment to alter their capital stock. Assume that the policy function of investment is:

$$
i_{i t}=i\left(\omega_{i t}, k_{i t}\right)
$$

and the function is invertible, we can write:

$$
\omega_{i t}=h\left(i_{i t}, k_{i t}\right)
$$

Then the production function becomes:

$$
y_{i t}=\beta_{l} l_{i t}+\phi\left(i_{i t}, k_{i t}\right)+\eta_{i t}
$$

in which $\phi\left(i_{i t}, k_{i t}\right)=\beta_{0}+\beta_{k} k_{i t}+h\left(i_{i t}, k_{i t}\right)$.

Another assumption is that firm survival, $\chi_{i t}$, occurs with a probability that is increasing 
with $\omega$. Then we can write:

$$
\begin{aligned}
E\left[y_{i t+1}-\beta_{l} l_{i t+1}\right] & =\beta_{0}+\beta_{k} k_{i t+1}+E\left[\omega_{i t+1} \mid \omega_{i t}, \chi_{i t+1}=1\right] \\
& =\beta_{0}+\beta_{k} k_{i t+1}+g\left(\omega_{i t}, \operatorname{Pr}\left(\chi_{i t+1}=1\right)\right)
\end{aligned}
$$

Following the model above, we adopt a three-step procedure to estimate TFP. In the first step, we regress the output variable $y$ on the labor input $l$ and a polynomial of investment $i$ and capital $k$ :

$$
y_{i t}=\beta_{l} l_{i t}+\phi\left(i_{i t}, k_{i t}\right)+\mu_{s t}+\eta_{i t}
$$

This step results in an unbiased estimate of the labor coefficient, $\hat{\beta}_{l}$, and an estimate of the function $\phi\left(i_{i t}, k_{i t}\right), \hat{\phi}_{i t}$. Because our analysis covers multiple industries with different market structure and factor prices, we include a SIC3 industry-specific year fixed effect, $\mu_{s t}$, in the regression.

In the second step, we estimate the survival function of all firms in the following regression model:

$$
\operatorname{Pr}\left[\chi_{i t}=1 \mid X_{i t}\right]=F\left(\gamma\left(i_{i t}, k_{i t}\right)+\nu_{i t}\right)
$$

In which $F(\cdot)$ is a probit model, $\gamma(\cdot)$ is a third-order polynomial, and $\nu$ is the error term. This step leads to a semi-parametric estimation of the survival function, $\hat{P}_{i t}$.

in the third step, we estimate the following equation:

$$
y_{i t}-\mu_{s t}-\hat{\beta}_{l} l_{i t}=\beta_{k} k_{i t}+\rho \omega_{i t-1}+\tau \hat{P}_{i t-1}+\eta_{i t}
$$

where $\omega_{i t}=\phi_{i t}-\beta_{0}-\beta_{k} k_{i t}$ is assumed to follow an $A R(1)$ process. The regression is estimated using nonlinear least squares, and an unbiased estimate of $\beta_{k}$ is given in the estimation results.

We finally compute the productivity as:

$$
T F P_{i t}=y_{i t}-\hat{\beta}_{0}-\mu_{s t}-\hat{\beta}_{l} l_{i t}-\hat{\beta}_{k} k_{i t}
$$

Notice that we exclude the industry-specific shifters $\mu_{s t}$ from the TFP estimates. This is to ensure that the industry-specific market structure or markups do not affect the TFP estimation. 


\section{B KZ index and Lerner Index}

Our construction of the Kaplan-Zingales index (Kaplan and Zingales (1997)) mainly follows (Almeida et al. (2004)), in which they provide a formula of firm-level KZ index:

$$
\begin{aligned}
\text { KZindex }= & -1.002 \times \text { Cash Flow }+0.283 \times Q+3.139 \times \text { Leverage } \\
& -39.368 \times \text { Dividends }-1.315 \times \text { Cash Holdings }
\end{aligned}
$$

For each of Tobin's Q, leverage, dividends, and cash holding, we winsorize them at the upper $1 \%$ level; and we winsorize cash flow to the range $[-1,1]$. The key variables used in computing KZ index are constructed as follows.

1. Cash flow: it is measured as income before extraordinary items (IB) plus depreciation and amortization (DP) normalized by the total asset (AT) in the previous year.

2. Tobin's Q: it is measured as total asset (AT) less book value of equity plus market value of equity normalized by total asset, in which book value of equity is measured as total asset (AT) less total liability (LT) and liquidation value of preferred stock (PSTKL) ${ }^{15}$ plus deferred taxes and investment tax credit (TXDITC), and market value of equity is measured by the annual closing price (PRCC from CRSP) of last year multiplied by common shares outstanding (CSHO from CRSP).

3. Leverage: it is measured as total debt in current liabilities (DLC) plus total long-term debt (DLTT) normalized by the total asset (AT).

4. Dividends: it is measure as common/Ordinary dividends plus preferred/preference dividends normalized by the total asset (AT) in the previous year.

5. Cash Holding: it is measured as cash and short-term investments (CHE) normalized by the total asset (AT) in the previous year.

We mainly follow Datta et al. (2013) to construct the Lerner Index (Lerner (1934)) using variables in Compustat:

$$
\text { Lerner Index }=\frac{\text { Net operating profits }}{\text { Sales }}=(S A L E-C O G S-X S G A) / S A L E
$$

\footnotetext{
${ }^{15}$ The item is replaced by redeemable preferred/preference stock (PSTKR) if PSTKL is missing.
} 
We winsorize Lerner Index to the range of $[-1,1]$ to eliminate the effect of extreme values. 


\section{Robustness Checks}

We gauge the robustness of our results to alternative specifications. Specifically, we show that the reallocation results remain when we 1) use alternative measures of import competition; 2) estimate the model using a non-overlapping sample; (3) control for sales in foreign markets and 4) adopt six-year differences.

\section{C.1 Alternative measures of import competition}

Following Bloom et al. (2016), we try two other measures of import competition by industry, namely Chinese imports as a share of U.S. production and Chinese imports as a share of total imports to the U.S.

With both alternative measures, import competition does not significantly reduce firm-level R\&D expenditures (Table C1 and Table C2). This may be due to the fact that either measure captures an incomplete part of industrial activities. Our preferred measure of import competition scaled by apparent consumption, i.e. production+imports-exports, has the advantage of incorporating both domestic production and imports.

Despite insignificant average effects, the reallocation effects remain significant for both alternative measures, as shown in Table C3 and C4. Firms with productivity and profitability above industry mean increased $\mathrm{R} \& \mathrm{D}$ expenditures in response to intensified competition from China. The reallocation effects are especially strong when we scale Chinese imports by total imports. 
Table C1: Average Effects of Import Competition (Measure 2)

\begin{tabular}{|c|c|c|c|c|c|c|}
\hline & \multicolumn{2}{|c|}{ OLS } & \multicolumn{4}{|c|}{ 2SLS } \\
\hline & $\begin{array}{l}(1) \\
\text { All }\end{array}$ & $\begin{array}{l}(2) \\
\text { All }\end{array}$ & $\begin{array}{l}(3) \\
\text { All }\end{array}$ & $\begin{array}{l}(4) \\
\text { All }\end{array}$ & $\begin{array}{c}(5) \\
\text { High-tech }\end{array}$ & $\begin{array}{c}(6) \\
\text { Balanced Panel } \\
\end{array}$ \\
\hline$\Delta$ Imp. Comp.2,US & $\begin{array}{c}-0.362^{* * *} \\
(0.132)\end{array}$ & $\begin{array}{c}-0.464^{* * *} \\
(0.128)\end{array}$ & $\begin{array}{l}-0.921 \\
(0.611)\end{array}$ & $\begin{array}{l}-1.129 \\
(0.744)\end{array}$ & $\begin{array}{l}-1.259 \\
(0.893)\end{array}$ & $\begin{array}{l}-1.335 \\
(0.834)\end{array}$ \\
\hline L5.log Asset & & $\begin{array}{c}0.010 \\
(0.008)\end{array}$ & & $\begin{array}{c}0.009 \\
(0.008)\end{array}$ & $\begin{array}{c}0.008 \\
(0.008)\end{array}$ & $\begin{array}{c}0.004 \\
(0.009)\end{array}$ \\
\hline L5.Market to Book Ratio & & $\begin{array}{l}0.010^{*} \\
(0.006)\end{array}$ & & $\begin{array}{c}0.010^{*} \\
(0.006)\end{array}$ & $\begin{array}{c}0.010 \\
(0.006)\end{array}$ & $\begin{array}{l}0.009^{*} \\
(0.005)\end{array}$ \\
\hline L5.KZ & & $\begin{array}{c}-0.020^{* * *} \\
(0.005)\end{array}$ & & $\begin{array}{c}-0.020^{* * *} \\
(0.005)\end{array}$ & $\begin{array}{c}-0.021^{* * *} \\
(0.005)\end{array}$ & $\begin{array}{c}-0.018^{* * *} \\
(0.006)\end{array}$ \\
\hline $\begin{array}{l}\text { First-stage F statistic } \\
\mathrm{N}\end{array}$ & 13200 & 11222 & $\begin{array}{l}16.388 \\
13200\end{array}$ & $\begin{array}{l}18.784 \\
11222\end{array}$ & $\begin{array}{c}15.484 \\
9135\end{array}$ & $\begin{array}{c}16.983 \\
9161\end{array}$ \\
\hline
\end{tabular}

Standard errors in parentheses

${ }^{*} p<0.10,{ }^{* *} p<0.05,{ }^{* * *} p<0.01$

Note: The sample includes U.S. manufacturing firms in Compustat from 1995 to 2009. Import competition is measured as Chinese imports as a share of U.S. production. Firm- and year-fixed effects are controlled, and standard errors are clustered by industry. Dependent variables are winsorized at the top 1 percent.

Table C2: Average Effects of Import Competition (Measure 3)

\begin{tabular}{|c|c|c|c|c|c|c|}
\hline & \multicolumn{2}{|c|}{$\overline{\text { OLS }}$} & \multicolumn{4}{|c|}{2 2SLS } \\
\hline & $\begin{array}{l}(1) \\
\text { All }\end{array}$ & $\begin{array}{l}(2) \\
\text { All }\end{array}$ & $\begin{array}{l}\text { (3) } \\
\text { All }\end{array}$ & $\begin{array}{l}\text { (4) } \\
\text { All }\end{array}$ & $\begin{array}{c}(5) \\
\text { High-tech }\end{array}$ & $\begin{array}{c}(6) \\
\text { Balanced Panel }\end{array}$ \\
\hline$\Delta$ Imp. Comp.3,US & $\begin{array}{l}-0.305 \\
(0.302)\end{array}$ & $\begin{array}{l}-0.311 \\
(0.294)\end{array}$ & $\begin{array}{l}-0.200 \\
(0.348)\end{array}$ & $\begin{array}{l}-0.267 \\
(0.381)\end{array}$ & $\begin{array}{l}-0.451 \\
(0.390)\end{array}$ & $\begin{array}{l}-0.501 \\
(0.396)\end{array}$ \\
\hline L5.log Asset & & $\begin{array}{c}0.005 \\
(0.010)\end{array}$ & & $\begin{array}{c}0.005 \\
(0.010)\end{array}$ & $\begin{array}{c}0.008 \\
(0.010)\end{array}$ & $\begin{array}{c}0.005 \\
(0.012)\end{array}$ \\
\hline L5.Market to Book Ratio & & $\begin{array}{c}0.015^{* * *} \\
(0.004)\end{array}$ & & $\begin{array}{c}0.015^{* * *} \\
(0.005)\end{array}$ & $\begin{array}{c}0.014^{* * *} \\
(0.005)\end{array}$ & $\begin{array}{l}0.013^{* *} \\
(0.005)\end{array}$ \\
\hline L5.KZ & & $\begin{array}{c}-0.033^{* * *} \\
(0.010)\end{array}$ & & $\begin{array}{c}-0.034^{* * *} \\
(0.010)\end{array}$ & $\begin{array}{c}-0.032^{* * *} \\
(0.010)\end{array}$ & $\begin{array}{c}-0.028^{* * *} \\
(0.009)\end{array}$ \\
\hline $\begin{array}{l}\text { First-stage F statistic } \\
\mathrm{N}\end{array}$ & 8206 & 7651 & $\begin{array}{l}15.209 \\
8206\end{array}$ & $\begin{array}{c}14.877 \\
7651\end{array}$ & $\begin{array}{c}13.747 \\
6180\end{array}$ & $\begin{array}{c}15.208 \\
6473\end{array}$ \\
\hline
\end{tabular}

Note: The sample includes U.S. manufacturing firms in Compustat from 1995 to 2009. Import competition is measured as Chinese imports as a share of total imports to the U.S. by industry. Firm- and year-fixed effects are controlled, and standard errors are clustered by industry. Dependent variables are winsorized at the top 1 percent. 
Table C3: Within-Industry Reallocation Results (Measure 2)

\begin{tabular}{|c|c|c|c|c|}
\hline & $\begin{array}{c}(1) \\
\Delta \log R \& D\end{array}$ & $\begin{array}{c}(2) \\
\Delta \log R \& D\end{array}$ & $\begin{array}{c}(3) \\
\Delta \log R \& D\end{array}$ & $\begin{array}{c}(4) \\
\Delta \log R \& D\end{array}$ \\
\hline$\Delta$ Imp. Comp.2,US & $\begin{array}{l}-1.129 \\
(0.744)\end{array}$ & $\begin{array}{c}-0.818^{* *} \\
(0.371)\end{array}$ & $\begin{array}{c}-0.822^{* *} \\
(0.383)\end{array}$ & $\begin{array}{c}-0.966^{* *} \\
(0.388)\end{array}$ \\
\hline$\Delta$ Imp. Comp $\times$ L5.TFP & & $\begin{array}{c}0.452^{*} \\
(0.269)\end{array}$ & & \\
\hline L5.TFP (Olley-Pakes) & & $\begin{array}{c}0.117^{* * *} \\
(0.035)\end{array}$ & & \\
\hline$\Delta$ Imp. Comp $\times$ L5.Labor productivity & & & $\begin{array}{l}0.796^{*} \\
(0.423)\end{array}$ & \\
\hline L5.Labor productivity & & & $\begin{array}{l}0.093^{* *} \\
(0.040)\end{array}$ & \\
\hline$\Delta$ Imp. Comp $\times$ L5.Profit margin & & & & $\begin{array}{l}0.621^{* *} \\
(0.297)\end{array}$ \\
\hline L5.Profit margin & & & & $\begin{array}{c}0.222^{* * *} \\
(0.030)\end{array}$ \\
\hline $\begin{array}{l}\text { First-stage F statistic } \\
\mathrm{N}\end{array}$ & $\begin{array}{l}18.784 \\
11222\end{array}$ & $\begin{array}{c}11.738 \\
8146\end{array}$ & $\begin{array}{c}11.708 \\
8146\end{array}$ & $\begin{array}{c}12.395 \\
9622\end{array}$ \\
\hline
\end{tabular}

Standard errors in parentheses

${ }^{*} p<0.10,{ }^{* *} p<0.05,{ }^{* * *} p<0.01$

Note: The sample includes U.S. manufacturing firms in Compustat from 1995 to 2009. Firm- and year-fixed effects are controlled, and standard errors are clustered by industry. Dependent variables are winsorized at the top 1 percent. 
Table C4: Within-Industry Reallocation Results (Measure 3)

\begin{tabular}{|c|c|c|c|c|}
\hline & $\begin{array}{c}(1) \\
\Delta \log R \& D\end{array}$ & $\begin{array}{c}(2) \\
\Delta \log R \& D\end{array}$ & $\begin{array}{c}(3) \\
\Delta \log R \& D\end{array}$ & $\begin{array}{c}(4) \\
\Delta \log R \& D\end{array}$ \\
\hline$\Delta$ Imp. Comp.3,US & $\begin{array}{l}-0.267 \\
(0.381)\end{array}$ & $\begin{array}{l}-0.362 \\
(0.417)\end{array}$ & $\begin{array}{l}-0.337 \\
(0.410)\end{array}$ & $\begin{array}{l}-0.562 \\
(0.416)\end{array}$ \\
\hline$\Delta$ Imp. Comp $\times$ L5.TFP & & $\begin{array}{c}0.847^{* * *} \\
(0.284)\end{array}$ & & \\
\hline L5.TFP (Olley-Pakes) & & $\begin{array}{c}0.108^{* * *} \\
(0.032)\end{array}$ & & \\
\hline$\Delta$ Imp. Comp $\times$ L5.Labor productivity & & & $\begin{array}{l}1.148^{* *} \\
(0.453)\end{array}$ & \\
\hline L5.Labor productivity & & & $\begin{array}{l}0.098^{* *} \\
(0.045)\end{array}$ & \\
\hline$\Delta$ Imp. Comp $\times$ L5.Profit margin & & & & $\begin{array}{c}1.016^{* * *} \\
(0.371)\end{array}$ \\
\hline L5.Profit margin & & & & $\begin{array}{c}0.189^{* * *} \\
(0.042)\end{array}$ \\
\hline $\begin{array}{l}\text { First-stage F statistic } \\
\mathrm{N}\end{array}$ & $\begin{array}{c}14.877 \\
7651\end{array}$ & $\begin{array}{l}7.499 \\
7651\end{array}$ & $\begin{array}{l}7.700 \\
7651\end{array}$ & $\begin{array}{l}7.435 \\
7377\end{array}$ \\
\hline $\begin{array}{l}\text { Standard errors in parentheses } \\
{ }^{*} p<0.10,{ }^{* *} p<0.05,{ }^{* * *} p<0.01\end{array}$ & & & & \\
\hline
\end{tabular}

\section{C.2 Non-overlapping differences}

In the main specification, we maximize the use of the data by using overlapping five-year differences. Here we show that both the average effects (Table C5) and the reallocation effects (Table C6) are robust to using non-overlapping differences. The only exception is the insignificant reallocation effect towards more profitable firms, probably due to smaller samples. 
Table C5: Average Effects of Import Competition (Non-Overlapping Sample)

\begin{tabular}{|c|c|c|c|c|c|c|}
\hline & \multicolumn{2}{|c|}{$\overline{\text { OLS }}$} & \multicolumn{4}{|c|}{$\overline{2 \text { SLS }}$} \\
\hline & $\begin{array}{l}(1) \\
\text { All }\end{array}$ & $\begin{array}{l}(2) \\
\text { All }\end{array}$ & $\begin{array}{l}(3) \\
\text { All }\end{array}$ & $\begin{array}{l}\text { (4) } \\
\text { All }\end{array}$ & $\begin{array}{c}(5) \\
\text { High-tech }\end{array}$ & $\begin{array}{c}(6) \\
\text { Balanced Panel }\end{array}$ \\
\hline$\Delta$ Imp. Comp.1,US & $\begin{array}{c}-0.912^{* * *} \\
(0.308)\end{array}$ & $\begin{array}{c}-0.889^{* * *} \\
(0.323)\end{array}$ & $\begin{array}{c}-0.654^{* *} \\
(0.309)\end{array}$ & $\begin{array}{c}-0.626^{* *} \\
(0.270)\end{array}$ & $\begin{array}{c}-0.742^{* *} \\
(0.323)\end{array}$ & $\begin{array}{l}-0.554^{*} \\
(0.320)\end{array}$ \\
\hline L5.log Asset & & $\begin{array}{l}-0.004 \\
(0.012)\end{array}$ & & $\begin{array}{l}-0.003 \\
(0.012)\end{array}$ & $\begin{array}{l}-0.008 \\
(0.013)\end{array}$ & $\begin{array}{l}-0.005 \\
(0.014)\end{array}$ \\
\hline L5.Market to Book Ratio & & $\begin{array}{l}0.017^{*} \\
(0.009)\end{array}$ & & $\begin{array}{l}0.017^{*} \\
(0.009)\end{array}$ & $\begin{array}{l}0.018^{*} \\
(0.010)\end{array}$ & $\begin{array}{l}0.014^{*} \\
(0.008)\end{array}$ \\
\hline L5.KZ & & $\begin{array}{c}-0.018^{* *} \\
(0.007)\end{array}$ & & $\begin{array}{c}-0.018^{* *} \\
(0.007)\end{array}$ & $\begin{array}{c}-0.018^{* *} \\
(0.008)\end{array}$ & $\begin{array}{c}-0.023^{* *} \\
(0.010)\end{array}$ \\
\hline $\begin{array}{l}\text { First-stage F statistic } \\
\mathrm{N}\end{array}$ & 2616 & 2283 & $\begin{array}{l}47.775 \\
2616\end{array}$ & $\begin{array}{c}52.486 \\
2283\end{array}$ & $\begin{array}{c}43.391 \\
1869\end{array}$ & $\begin{array}{l}69.795 \\
1887\end{array}$ \\
\hline
\end{tabular}

Standard errors in parentheses

${ }^{*} p<0.10,{ }^{* *} p<0.05,{ }^{* * *} p<0.01$

Note: The sample includes U.S. manufacturing firms in Compustat in 1997, 2002 and 2007. Firm- and year-fixed effects are controlled, and standard errors are clustered by industry. Dependent variables are winsorized at the top 1 percent.

Table C6: Within-Industry Reallocation Results (Non-Overlapping Sample)

\begin{tabular}{|c|c|c|c|c|}
\hline & $\begin{array}{c}(1) \\
\Delta \log R \& D\end{array}$ & $\begin{array}{c}(2) \\
\Delta \log R \& D\end{array}$ & $\begin{array}{c}(3) \\
\Delta \log R \& D\end{array}$ & $\begin{array}{c}(4) \\
\Delta \log R \& D\end{array}$ \\
\hline$\Delta$ Imp. Comp.1,US & $\begin{array}{c}-0.626^{* *} \\
(0.270)\end{array}$ & $\begin{array}{c}-1.069^{* * *} \\
(0.342)\end{array}$ & $\begin{array}{c}-0.948^{* *} \\
(0.367)\end{array}$ & $\begin{array}{c}-0.896^{* *} \\
(0.392)\end{array}$ \\
\hline$\Delta$ Imp. Comp $\times$ L5.TFP & & $\begin{array}{l}1.526^{* *} \\
(0.592)\end{array}$ & & \\
\hline L5.TFP (Olley-Pakes) & & $\begin{array}{l}0.074^{*} \\
(0.042)\end{array}$ & & \\
\hline$\Delta$ Imp. Comp $\times$ L5.Labor productivity & & & $\begin{array}{c}2.035^{* * *} \\
(0.654)\end{array}$ & \\
\hline L5.Labor productivity & & & $\begin{array}{c}-0.003 \\
(0.049)\end{array}$ & \\
\hline$\Delta$ Imp. Comp $\times$ L5.Profit margin & & & & $\begin{array}{c}0.761 \\
(0.523)\end{array}$ \\
\hline L5.Profit margin & & & & $\begin{array}{c}0.211^{* * *} \\
(0.045)\end{array}$ \\
\hline $\begin{array}{l}\text { First-stage F statistic } \\
\mathrm{N}\end{array}$ & $\begin{array}{c}52.486 \\
2283\end{array}$ & $\begin{array}{l}9.262 \\
1811\end{array}$ & $\begin{array}{l}7.352 \\
1811\end{array}$ & $\begin{array}{c}22.063 \\
1941\end{array}$ \\
\hline
\end{tabular}

Standard errors in parentheses

${ }^{*} p<0.10,{ }^{* *} p<0.05,{ }^{* * *} p<0.01$

Note: The sample includes U.S. manufacturing firms in Compustat in 1997, 2002 and 2007. Firm- and yearfixed effects are controlled, and standard errors are clustered by industry. Dependent variables are winsorized at the top 1 percent. 


\section{C.3 Other controls}

We choose the set of firm characteristics to include in the main specification based on the corporate finance literature. The average effects and reallocation effects remain unchanged when we control for firms' log sales and their share of foreign sales. As shown in Table C7, firms with increasing foreign presence tend to invest more on $R \& D$. The share of foreign sales serves as a proxy for firms' export volume, which has been growing rapidly since China joined the WTO in 2001. The firm-specific changes in foreign sales do not interfere with the industry-level import competition. Both the average effect (Table $\mathrm{C} 7$ ) and the reallocation effects (Table C8) stay significant with similar magnitudes as those in the main results.

Table C7: Average Effects of Import Competition (New Controls)

\begin{tabular}{|c|c|c|c|c|c|c|}
\hline & \multicolumn{2}{|c|}{ OLS } & \multicolumn{4}{|c|}{ 2SLS } \\
\hline & $\begin{array}{l}\text { (1) } \\
\text { All }\end{array}$ & $\begin{array}{l}\text { (2) } \\
\text { All }\end{array}$ & $\begin{array}{l}\text { (3) } \\
\text { All }\end{array}$ & $\begin{array}{l}\text { (4) } \\
\text { All }\end{array}$ & $\begin{array}{c}(5) \\
\text { High-tech }\end{array}$ & $\begin{array}{c}(6) \\
\text { Balanced Panel }\end{array}$ \\
\hline$\Delta$ Imp. Comp.1,US & $\begin{array}{c}-0.570^{* * *} \\
(0.211)\end{array}$ & $\begin{array}{c}-0.567^{* * *} \\
(0.180)\end{array}$ & $\begin{array}{c}-0.572^{* *} \\
(0.246)\end{array}$ & $\begin{array}{c}-0.595^{* *} \\
(0.241)\end{array}$ & $\begin{array}{c}-0.689^{* *} \\
(0.268)\end{array}$ & $\begin{array}{c}-0.688^{* * *} \\
(0.241)\end{array}$ \\
\hline$\Delta$ in Share of Foreign Sales & $\begin{array}{c}0.339^{* * *} \\
(0.105)\end{array}$ & $\begin{array}{l}0.236^{* *} \\
(0.117)\end{array}$ & $\begin{array}{c}0.339^{* * *} \\
(0.105)\end{array}$ & $\begin{array}{l}0.236^{* *} \\
(0.117)\end{array}$ & $\begin{array}{l}0.203^{*} \\
(0.116)\end{array}$ & $\begin{array}{l}0.293^{* *} \\
(0.126)\end{array}$ \\
\hline L5.log Sales & & $\begin{array}{c}0.023^{* * *} \\
(0.006)\end{array}$ & & $\begin{array}{c}0.023^{* * *} \\
(0.006)\end{array}$ & $\begin{array}{c}0.022^{* * *} \\
(0.006)\end{array}$ & $\begin{array}{c}0.020^{* * *} \\
(0.006)\end{array}$ \\
\hline L5.Market to Book Ratio & & $\begin{array}{l}0.013^{* *} \\
(0.005)\end{array}$ & & $\begin{array}{l}0.013^{* *} \\
(0.005)\end{array}$ & $\begin{array}{l}0.013^{* *} \\
(0.006)\end{array}$ & $\begin{array}{c}0.012^{* * *} \\
(0.004)\end{array}$ \\
\hline L5.KZ & & $\begin{array}{c}-0.021^{* * *} \\
(0.004) \\
\end{array}$ & & $\begin{array}{c}-0.021^{* * *} \\
(0.004)\end{array}$ & $\begin{array}{c}-0.022^{* * *} \\
(0.005)\end{array}$ & $\begin{array}{c}-0.019^{* * *} \\
(0.006)\end{array}$ \\
\hline $\begin{array}{l}\text { First-stage F statistic } \\
\mathrm{N}\end{array}$ & 13209 & 11230 & $\begin{array}{l}17.618 \\
13209\end{array}$ & $\begin{array}{l}16.330 \\
11230\end{array}$ & $\begin{array}{c}16.240 \\
9135\end{array}$ & $\begin{array}{c}15.114 \\
9163\end{array}$ \\
\hline $\begin{array}{l}\text { Standard errors in parentheses } \\
{ }^{*} p<0.10,{ }^{* *} p<0.05,{ }^{* * *} p<0\end{array}$ & & & & & & \\
\hline
\end{tabular}


Table C8: Within-Industry Reallocation Results (New Controls)

\begin{tabular}{|c|c|c|c|c|}
\hline$\Delta$ Imp. Comp.1,US & $\begin{array}{c}1) \\
\Delta \log R \& D \\
-0.595^{* *} \\
(0.241)\end{array}$ & $\begin{array}{c}(2) \\
\Delta \log \mathrm{R} \& \mathrm{D} \\
-0.536^{* *} \\
(0.212)\end{array}$ & $\begin{array}{c}(3) \\
\Delta \log \mathrm{R} \& \mathrm{D} \\
-0.512^{* *} \\
(0.214)\end{array}$ & $\begin{array}{c}(4) \\
\Delta \log \mathrm{R} \& \mathrm{D} \\
-0.653^{* * *} \\
(0.222)\end{array}$ \\
\hline$\Delta$ in Share of Foreign Sales & $\begin{array}{l}0.236^{* *} \\
(0.117)\end{array}$ & $\begin{array}{c}0.233 \\
(0.142)\end{array}$ & $\begin{array}{c}0.239^{*} \\
(0.142)\end{array}$ & $\begin{array}{l}0.245^{*} \\
(0.132)\end{array}$ \\
\hline$\Delta$ Imp. Comp $\times$ L5.TFP & & $\begin{array}{l}0.637^{* *} \\
(0.261)\end{array}$ & & \\
\hline L5.TFP (Olley-Pakes) & & $\begin{array}{c}0.083^{* * *} \\
(0.030)\end{array}$ & & \\
\hline$\Delta$ Imp. Comp $\times$ L5.Labor productivity & & & $\begin{array}{l}1.078^{* *} \\
(0.487)\end{array}$ & \\
\hline L5.Labor productivity & & & $\begin{array}{c}0.043 \\
(0.039)\end{array}$ & \\
\hline$\Delta$ Imp. Comp $\times$ L5.Profit margin & & & & $\begin{array}{c}0.631^{* * *} \\
(0.225)\end{array}$ \\
\hline L5.Profit margin & & & & $\begin{array}{c}0.236^{* * *} \\
(0.027)\end{array}$ \\
\hline $\begin{array}{l}\text { First-stage F statistic } \\
\mathrm{N}\end{array}$ & $\begin{array}{l}16.330 \\
11230\end{array}$ & $\begin{array}{l}7.603 \\
8146\end{array}$ & $\begin{array}{l}7.655 \\
8146\end{array}$ & $\begin{array}{l}7.928 \\
9628\end{array}$ \\
\hline $\begin{array}{l}\text { Standard errors in parentheses } \\
{ }^{*} p<0.10,{ }^{* *} p<0.05,{ }^{* * *} p<0.01\end{array}$ & & & & \\
\hline
\end{tabular}

\section{C.4 Six-year differences}

Our baseline results are also robust to using six-year differences. Based on Table C9), a 10 percentage point increase in import competition would reduce average $R \& D$ expenditures by six percent, similar to the $6.4 \%$ estimated in main results. The reallocation effects (Table C10) are also significant with similar magnitudes as in main results. 
Table C9: Average Effects of Import Competition (Six-Year Difference)

\begin{tabular}{|c|c|c|c|c|c|c|}
\hline & \multicolumn{2}{|c|}{ OLS } & \multicolumn{4}{|c|}{2 2SLS } \\
\hline & $\begin{array}{l}\text { (1) } \\
\text { All }\end{array}$ & $\begin{array}{l}(2) \\
\text { All }\end{array}$ & $\begin{array}{l}\text { (3) } \\
\text { All }\end{array}$ & $\begin{array}{l}(4) \\
\text { All }\end{array}$ & $\begin{array}{c}(5) \\
\text { High-tech }\end{array}$ & $\begin{array}{c}(6) \\
\text { Balanced Panel }\end{array}$ \\
\hline$\Delta$ Imp. Comp.1,US & $\begin{array}{c}-0.682^{* *} \\
(0.306)\end{array}$ & $\begin{array}{c}-0.679^{* * *} \\
(0.254)\end{array}$ & $\begin{array}{l}-0.601 \\
(0.369)\end{array}$ & $\begin{array}{l}-0.602^{*} \\
(0.323)\end{array}$ & $\begin{array}{c}-0.767^{* *} \\
(0.337)\end{array}$ & $\begin{array}{c}-0.747^{* *} \\
(0.340)\end{array}$ \\
\hline L6.log Asset & & $\begin{array}{c}0.006 \\
(0.010)\end{array}$ & & $\begin{array}{c}0.006 \\
(0.010)\end{array}$ & $\begin{array}{c}0.007 \\
(0.010)\end{array}$ & $\begin{array}{c}0.005 \\
(0.011)\end{array}$ \\
\hline L6.Market to Book Ratio & & $\begin{array}{c}0.010 \\
(0.007)\end{array}$ & & $\begin{array}{c}0.010 \\
(0.007)\end{array}$ & $\begin{array}{c}0.009 \\
(0.008)\end{array}$ & $\begin{array}{l}0.010^{*} \\
(0.006)\end{array}$ \\
\hline L6.KZ & & $\begin{array}{c}-0.020^{* * *} \\
(0.005)\end{array}$ & & $\begin{array}{c}-0.020^{* * *} \\
(0.005)\end{array}$ & $\begin{array}{c}-0.019^{* * *} \\
(0.004)\end{array}$ & $\begin{array}{c}-0.017^{* * *} \\
(0.005)\end{array}$ \\
\hline $\begin{array}{l}\text { First-stage F statistic } \\
\mathrm{N}\end{array}$ & 11166 & 9489 & $\begin{array}{l}19.486 \\
11166\end{array}$ & $\begin{array}{c}17.306 \\
9489\end{array}$ & $\begin{array}{c}17.339 \\
7715\end{array}$ & $\begin{array}{c}16.625 \\
8053\end{array}$ \\
\hline
\end{tabular}

Note: The sample includes U.S. manufacturing firms in Compustat from 1995 to 2009 after cleaning. Firmand year-fixed effects are controlled, and standard errors are clustered by industry. Dependent variables are winsorized at the top 1 percent.

Table C10: Within-Industry Reallocation Results (Six-Year Difference)

\begin{tabular}{|c|c|c|c|c|}
\hline & $\begin{array}{c}(1) \\
\Delta \log R \& D\end{array}$ & $\begin{array}{c}(2) \\
\Delta \log R \& D \\
\end{array}$ & $\begin{array}{c}(3) \\
\Delta \log R \& D\end{array}$ & $\begin{array}{c}(4) \\
\Delta \log R \& D\end{array}$ \\
\hline$\Delta$ Imp. Comp.1,US & $\begin{array}{l}-0.602^{*} \\
(0.323)\end{array}$ & $\begin{array}{l}-0.467 \\
(0.299)\end{array}$ & $\begin{array}{l}-0.425 \\
(0.312)\end{array}$ & $\begin{array}{c}-0.766^{* *} \\
(0.332)\end{array}$ \\
\hline$\Delta$ Imp. Comp $\times$ L6.TFP & & $\begin{array}{l}0.699^{* *} \\
(0.303)\end{array}$ & & \\
\hline L6.TFP (Olley-Pakes) & & $\begin{array}{l}0.098^{* *} \\
(0.038)\end{array}$ & & \\
\hline$\Delta$ Imp. Comp $\times$ L6.Labor productivity & & & $\begin{array}{l}1.023^{*} \\
(0.519)\end{array}$ & \\
\hline L6.Labor productivity & & & $\begin{array}{c}0.062 \\
(0.051)\end{array}$ & \\
\hline$\Delta$ Imp. Comp $\times$ L6.Profit margin & & & & $\begin{array}{c}0.952^{* * *} \\
(0.273)\end{array}$ \\
\hline L6.Profit margin & & & & $\begin{array}{c}0.216^{* * *} \\
(0.034)\end{array}$ \\
\hline $\begin{array}{l}\text { First-stage F statistic } \\
\mathrm{N}\end{array}$ & $\begin{array}{c}17.306 \\
9489\end{array}$ & $\begin{array}{l}8.140 \\
6805\end{array}$ & $\begin{array}{l}8.409 \\
6805\end{array}$ & $\begin{array}{l}8.369 \\
8126\end{array}$ \\
\hline
\end{tabular}

Standard errors in parentheses

${ }^{*} p<0.10,{ }^{* *} p<0.05,{ }^{* * *} p<0.01$

Note: The sample includes U.S. manufacturing firms in Compustat from 1995 to 2009 after cleaning. Firmand year-fixed effects are controlled, and standard errors are clustered by industry. Dependent variables are winsorized at the top 1 percent. 


\section{Aggregating Firm-level Effects: Derivation}

We evaluate the aggregate effect of import competition on R\&D expenditures by U.S. public firms by summing up the average effect and the reallocation effect across firms. Assuming that there are no firm entry and exit, the growth rate of aggregate $R \& D$ can be decomposed as the following:

$$
\begin{aligned}
\frac{X_{1}-X_{0}}{X_{0}} & =\frac{\sum_{i=1}^{N}\left(x_{i 1}-x_{i 0}\right)}{\sum_{i=1}^{N} x_{i 0}}+\frac{\sum_{i \in \text { entrant }} x_{i 1}-\sum_{i \in \text { exit }} x_{i 0}}{\sum_{i=1}^{N} x_{i 0}} \\
& =\frac{\sum_{i=1}^{N} \frac{\left(x_{i 1}-x_{i 0}\right)}{x_{i 0}} \cdot \bar{x}_{0}+\sum_{i=1}^{N} \frac{\left(x_{i 1}-x_{i 0}\right)}{x_{i 0}} \cdot\left(x_{i 0}-\bar{x}_{0}\right)}{\sum_{i=1}^{N} x_{i 0}}+\frac{1}{N} \sum_{i \in \text { entrant }} \frac{x_{i 1}}{\bar{x}_{0}}-\frac{1}{N} \sum_{i \in \text { exit }} \frac{x_{i 0}}{\bar{x}_{0}} \\
& =\frac{1}{N} \sum_{i=1}^{N} \frac{\left(x_{i 1}-x_{i 0}\right)}{x_{i 0}}+\frac{1}{N} \sum_{i=1}^{N} \frac{\left(x_{i 1}-x_{i 0}\right)}{x_{i 0}} \cdot \frac{\left(x_{i 0}-\bar{x}_{0}\right)}{\bar{x}_{0}} \\
& +\frac{1}{N} \sum_{i \in \Omega_{1}} \mathbf{1}(i \in \text { entrant }) \frac{x_{i 1}}{\bar{x}_{0}}-\frac{1}{N} \sum_{i \in \Omega_{0}} \mathbf{1}(i \in \text { exit }) \frac{x_{i 0}}{\bar{x}_{0}}
\end{aligned}
$$

where $X_{0}$ denotes the initial aggregate level of $\mathrm{R} \& \mathrm{D}$ and $X_{1}$ is the ending aggregate level of $\mathrm{R} \& \mathrm{D} ; X_{i 0}$ is the initial level of $\mathrm{R} \& \mathrm{D}$ for firm $i$ and $X_{i 1}$ is the ending level of $\mathrm{R} \& \mathrm{D}$ for firm $i$; $\bar{x}_{0}$ denotes the average level of initial level of $\mathrm{R} \& \mathrm{D}$; and $N$ is the total number of firms.

The above expression consists of four parts. The first part is the average effect (the average change of firms' $R \& D$ investment); the second is the reallocation effect (the shift of $R \& D$ investment from ex ante low R\&D firms to high R\&D firms); the third is the entry component (the increase in $\mathrm{R} \& \mathrm{D}$ from new entrants); the forth term is the exit component (the decrease in $R \& D$ from exiting firms). Because we do not observe the lagged productivity level of entrants, we cannot model the effect of import competition on new entrants. For the other three components, based on the approximation that $\frac{X_{1}-X_{0}}{X_{0}}=\ln \left(\frac{X_{1}}{X_{0}}\right)$ and $\frac{\left(x_{i 1}-x_{i 0}\right)}{x_{i 0}}=\ln \left(\frac{x_{i 1}}{x_{i 0}}\right)$, the impact of Chinese import competition on the growth of aggregate $R \& D$ can be written as:

$$
\begin{aligned}
\left(\frac{X_{1}-X_{0}}{X_{0}}\right)^{\text {China }}= & \frac{1}{N} \sum_{i=1}^{N} \alpha_{a v g} \cdot \Delta \operatorname{Imp}_{j}+\frac{1}{N} \sum_{i=1}^{N}\left(\alpha_{T F P} \cdot \Delta \operatorname{Imp} p_{j}+\gamma_{T F P} \cdot \Delta \operatorname{Imp}_{j} \cdot T F P_{i}\right) \\
& \cdot \frac{\left(x_{i 0}-\bar{x}_{0}\right)}{\bar{x}_{0}}-\frac{1}{N} \sum_{i \in \Omega_{0}}\left(-\alpha_{\text {Surv. }} \cdot \Delta \operatorname{Imp}_{j}-\gamma_{\text {Surv }} \cdot \Delta \operatorname{Imp} p_{j} \cdot T F P_{i}\right) \frac{x_{i 0}}{\bar{x}_{0}}
\end{aligned}
$$

in which $\alpha_{\text {avg }}=-0.640$ according to Table $3, \alpha_{T F P}=-0.584$ and $\gamma_{T F P}=0.683$ according to Table 4.

The coefficients $\alpha_{\text {Surv }}$. and $\gamma_{\text {Surv }}$. in the last term comes from regressing a survival indicator of 
all firms in the starting year on import competition, starting TFP level, and the interaction of the two variables. 